\title{
$\mathrm{UiO}$ : Faculty of Law University of Oslo
}

\section{The fall of Icarus? How states attract renewable energy investment claims}

Candidate number: 7003

Submission deadline: 01 December 2015

Number of words: 17946 


\section{Table of contents}

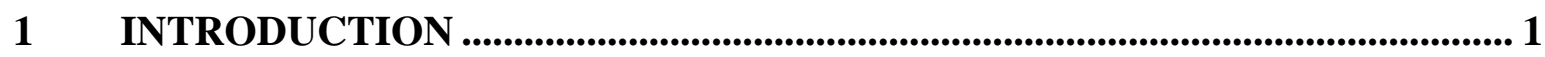

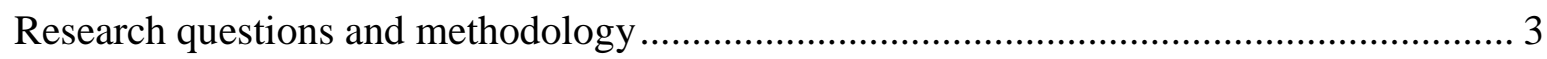

2 THE EU AND THE PV SOLAR BUBBLE: THE SLEEP OF REASON

PRODUCES MONSTERS.................................................................................................. 5

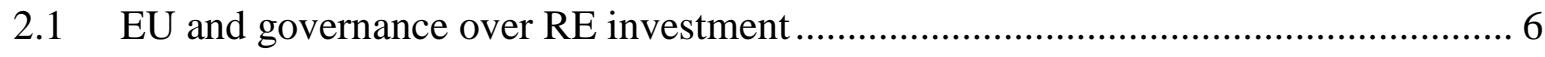

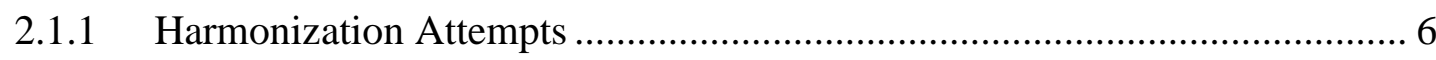

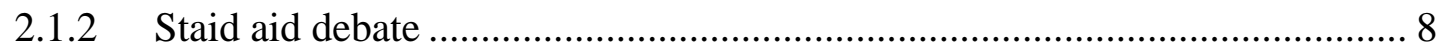

2.2 PV solar investment claims and EU investment treaties ......................................... 9

2.2.1 The Energy Charter Treaty .......................................................................... 10

2.2.2 The intra-EU Bilateral Investment Treaties .................................................. 11

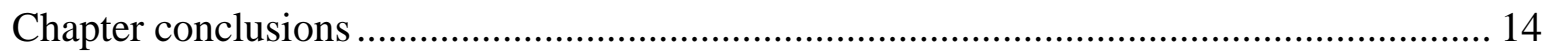

3 CASE STUDY: RENEWABLE INVESTMENT POLICIES IN EU MEMBER

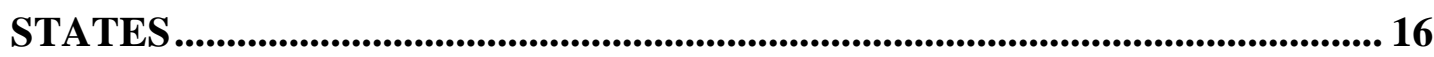

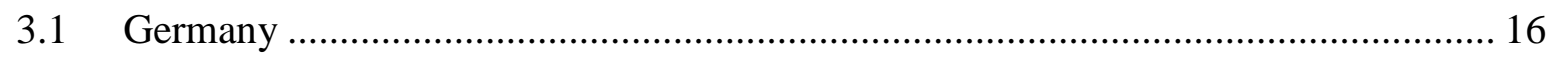

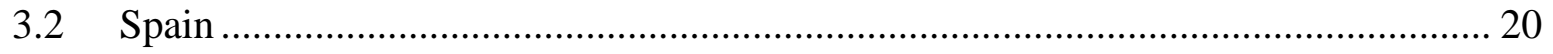

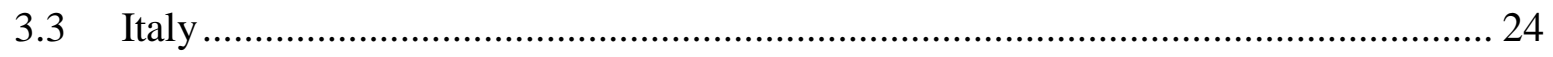

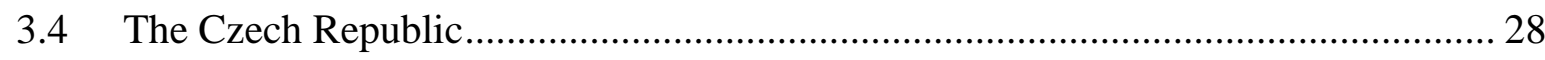

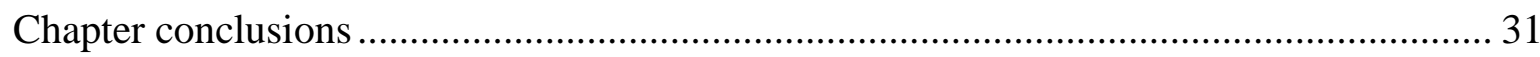

4 FACING THE AVALANCHE OF RENEWABLE ENERGY INVESTMENT

CLAIMS ..................................................................................................................................... 33 
4.1 The storm is coming: PV solar claims against EU Member States

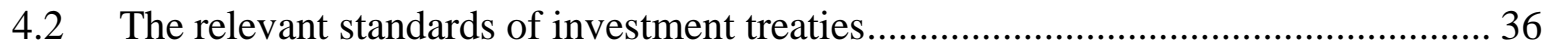

4.2.1 The fair and equitable treatment (FET) standard .......................................... 37

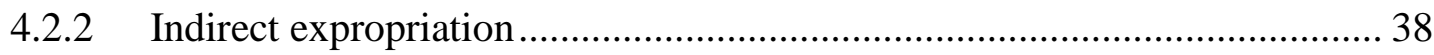

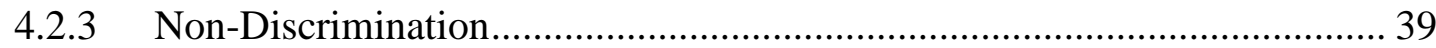

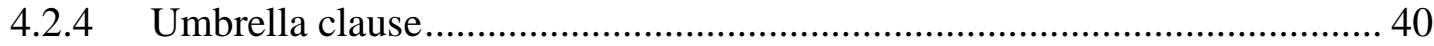

4.3 Promised pie in the sky: FET and RE investment claims........................................ 41

4.3.1 New restrictions to PV solar projects ......................................................... 42

4.3.2 Retroactive and retrospective application of reductions ............................... 44

4.3.3 Lack of transparency in decision making process........................................ 46

4.3.4 Failure to adopt mitigating measures ........................................................ 48

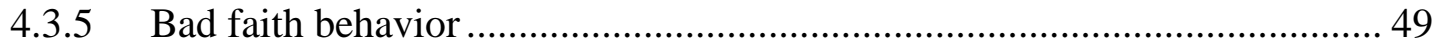

4.4 States in Different Leagues: What Influences the Caseload? ....................................50

Chapter conclusions: Fear the avalanche .......................................................................... 51

5 CONCLUSIONS ........................................................................................................... 53

6 BIBLIOGRAPHY .................................................................................................... 56

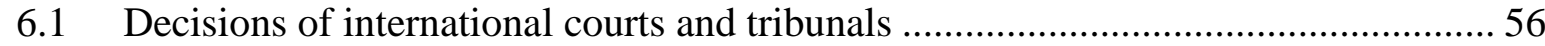

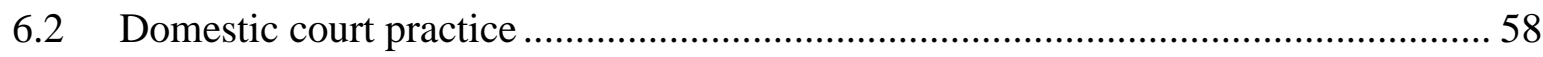

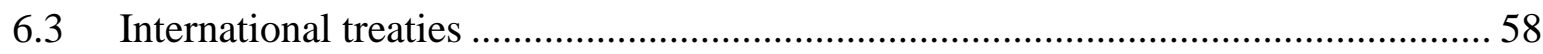

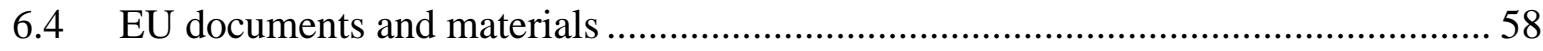

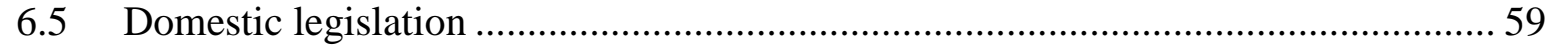

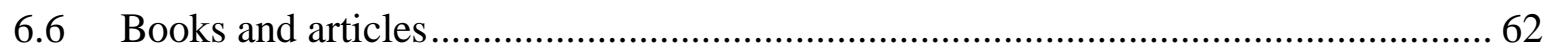

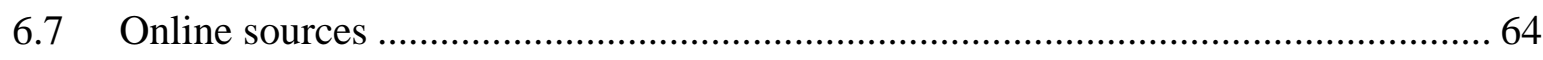




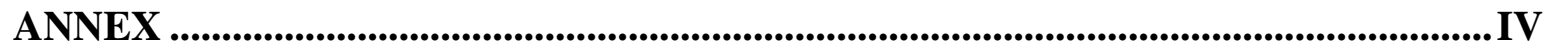




\section{Introduction}

Foreign investments between investors and the states hosting their investments can take many forms. The international legal framework for foreign investment is maintained primarily by the investment treaty regime, ${ }^{1}$ which covers questions of admission to the market, treatment by the host state and dispute settlement. The protected types of investment usually include property and property rights; shares and other participation rights in companies; rights arising from concessions and others. If a state violates these rights, the investor can refer to dispute settlement procedures in accordance with the investment treaty, usually, in the form of international arbitration. The majority of investment disputes arise in industries which are traditionally attractive for foreign investment (oil and gas, mining, real estate development and construction). They have been well described, and more or less predictable in terms of outcomes due to extensive arbitral practice.

A different situation appears in new industries in the modern era of globalization. New technological developments open the way to unprecedented areas of commercially attractive activities. However, in new sectors of the economy, states face a tabula rasa from the beginning, and thus diverge in approaches and often adopt contradictory policies.

This is exactly the case with investments in the renewable energy (RE) sector, which were developed during the last 30 years with a great variety of supporting measures. This thesis is focused on a new type of claims in the context of investment treaty law - claims concerning the support schemes to RE producers.

Due to the global scope of investment treaty arbitration (ITA), this thesis is intentionally limited so as to focus on a particular geographical scale (European Union (EU) and its Member States) and a particular subject-matter type of investment treaty arbitrations (RE disputes, specifically photovoltaic (PV) solar energy disputes).

First, the assessment of the relationship between ITA and the promotion of RE will be limited to certain EU Member States in order to show the variety of national policies within a

\footnotetext{
${ }^{1}$ Besides international treaties, the legal framework may be also based on investment contracts and host state legislation relating to foreign investment.
} 
centralized regulatory framework, helping to conduct a diversified assessment of policy measures and their potential impact on ITA proceedings. Assessment of these states' policies will also be curtailed as to focus on legislative and regulatory measures that have been claimed to violate provisions in investment treaties by negatively affecting the rights of private investors who have invested in the PV solar sector in selected EU Member States. Second, the assessment will be limited to ITAs that have arisen as a result of changes made to support schemes relating to the promotion of investments in the PV solar sector. This choice is reasoned by two connected facts. First, PV solar projects appear to be highly dependent on technological progress, which have gradually made PV solar panels more competitive with traditional energy sources. Second, empirical evidence demonstrates that the majority of RE investment claims filed to date have been related to PV solar projects. Accordingly, this thesis will concentrate on a particular type of support scheme - feed-in tariffs (FITs) - that have been the predominant means of incentivizing investment in PV solar projects. FITs may be described as a support scheme consisting of at least three design options: (i) an obligation to purchase energy, (ii) on a predefined tariff level and (iii) for a long duration of tariff payment. ${ }^{2}$ Other support measures (such as feed-in premiums, tradable green certificates, priority access to the electric grid, etc.) will be covered to the extent that these mechanisms may play a role in future ITAs.

Third, the assessment is limited to ITA claims, leaving aside the discussion over national court cases relating to changes in the incentivization of PV solar energy, which can be also quite extensive. ${ }^{3}$

The structure of the thesis will first discuss the EU-level policies relating to the incentivization of RE among its Member States and how these policies relate to the investment treaty

\footnotetext{
${ }^{2}$ David Jacobs, Renewable energy policy convergence in the EU: the evolution of feed-in tariffs in Germany, Spain and France (Ashgate Publishing 2012) 27.

${ }^{3}$ According to reports, at least than 125 lawsuits concerning renewables were accepted by the Spanish Supreme Court and about a 1000 lawsuits filed in domestic Italian courts (see 'Slew of Spanish lawsuits filed over renewable energy reforms' Africa, 2014) <http://af.reuters.com/article/energyOilNews/idAFL6N0RO4JP20140923> accessed 31.07.2015; Gaetano Iorio Fiorelli, 'Italy withdraws from Energy Charter Treaty' (Global Arbitration News, 2015) <http://globalarbitrationnews.com/italy-withdraws-from-energy-charter-treaty-20150507/> accessed 31.07.2015).
} 
regime and the rise in the number of ITAs based on changes to the support schemes in the PV solar sector specifically. Second, this thesis will conduct an empirical analysis of RE policies (abridged for focus on PV solar energy) in selected EU Member States by describing the background of regulation, response to EU Directives, further growth of incentives and the current reduction of support measures. Third, and based on a policy review, the thesis will analyze which national regulatory measures have formed the basis of investment treaty claims and examine what investment protections may be further invoked by specifically concentrating on the fair and equitable treatment (FET) standard due to its universal character and growing popularity in ITA. The final section of the thesis will identify the factors arising from the different number of ITA cases against EU Member States to date and provide insights into how these cases might be resolved and how they will affect future arbitral practice as well as future policy choices on the incentivization of RE among EU Member States.

\section{Research questions and methodology}

The general research question of this thesis is an inquiry into why states succeed and fail in their RE policies judging by the amount of investment treaty disputes that have been filed against them. Although the success in RE policies can be examined from different angles, assessment from the prospective of ITA is a novel approach.

The detailed research questions, which will be considered further, are as follows:

1. How have EU policies on the promotion of RE affected EU Member States' actions in regard to the design of support schemes and other incentivization mechanisms for encouraging investment in the RE sector?

2. How have these support schemes been implemented by EU Member States and what types of regulatory changes have triggered disputes arising out of these same states investment treaty obligations?

3. What are the common features of the RE sector ITA cases that have arisen as a result of support scheme changes among certain EU Member States? What standards under investment treaties are likely to be invoked in these cases?

4. What features of national RE policies might influence the incidence of ITA? What measures are currently being targeted in these disputes? What measures 
could be potentially targeted in states which have not faced RE-related ITA claims to date?

The analytical framework and methodological approach for addressing the research questions will include the following:

1. Analysis of primary legal sources (international acts, including the EU legal framework; national legislation and judicial decisions of selected EU Member States). With regard to national legislation, references to the original text of particular texts will be made where possible.

2. Analysis of legal doctrine in research of national RE policies and in the field of ITA.

3. Identification and empirical analysis of currently known RE investment cases, with the assistance of the PluriCourts Investment Treaty Arbitration Database (PITAD). 


\section{The EU and the PV solar bubble: the sleep of reason produces monsters}

The shift to a diversified energy supply and increased reliance on RE production within the EU has been on the agenda for decades. Following international obligations to limit carbon dioxide emissions, ${ }^{4}$ two principal directives were adopted within the EU. ${ }^{5}$ The first directive promoted the idea of RE support schemes among Member States, noting that EUwide support schemes at that time were too early due to the limited experience with national schemes and low share of RE among the Member States. ${ }^{6}$ While a mandatory Community-wide target of a 20 percent share of energy from renewable sources was set in $2007,{ }^{7}$ the implementation of this target goal was left to the EU Member States to achieve. The 2009 Directive introduced mandatory national targets and obliged Member States to establish national RE plans. ${ }^{8}$ The 2009 Directive specifically mentioned a need to guarantee the proper functioning of national support schemes in order to maintain investor confidence. ${ }^{9}$ Before shifting focus to the particulars of national support schemes, it is important to look a bit closer at: (i) the political influence of the EU on PV solar investment policies among its Member States; and (ii) changes in the intra-EU investment treaty regime related to PV solar investments. This section will show that EU governance, expressed primarily by the actions of the European Commission (Commission), is presenting problems for Member States in regard to state aid rules and application of intra-EU investment treaties.

\footnotetext{
${ }^{4}$ United Nations Framework Convention on Climate Change [1992]; Kyoto Protocol to the United Nations Framework Convention on Climate Change [1997].

${ }^{5}$ Directive (EC) 2001/77/EC of 27 September 2001 on the promotion of electricity produced from renewable energy sources in the internal electricity market [2001] OJ L 283/33; Directive (EC) 2009/28/EC of the European Parliament and of the Council of 23 April 2009 on the promotion of the use of energy from renewable sources and amending and subsequently repealing Directives 2001/77/EC and 2003/30/EC [2009] OJ L 140/16.

${ }^{6}$ Directive (EC) 2001/77/EC, Recital 15.

$\begin{array}{llll}{ }^{7} \text { European } & \text { Council } & \text { Presidency } & \text { Conclusions }\end{array}$ <http://www.consilium.europa.eu/uedocs/cms_data/docs/pressdata/en/ec/93135.pdf> accessed 30.09.2015, 21

${ }^{8}$ Directive (EC) 2009/28/EC, Recitals 13, 19, Articles 3-4.

${ }^{9}$ Ibid, Recital 25.
} 


\subsection{EU and governance over RE investment}

The European record of RE regulation includes a profound discussion over the scope of supranational governance and the level of convergence between national policies. Another dimension has a more practical character and is centered on the permissible state aid requirements. Accordingly, the following section will briefly address both of these issues, concluding on the scope of EU governance over national RE policies.

\subsubsection{Harmonization Attempts}

In the last fifteen years, the EU and its Member States undertook two less than successful attempts to harmonize the support measures for RE investment at the EU level. ${ }^{10}$ The failed attempts are partly attributable to the lack of direct competence over the energy sector before the introduction of the Lisbon Treaty, and partly due to the lack of agreement between the EU and its Member States on the appropriate harmonization measures. ${ }^{11}$ The $2009 \mathrm{Di}$ rective expressly adopted a restrictive approach ${ }^{12}$ towards the powers of EU to control national support schemes, thus limiting the harmonizing powers of EU as a centralized authority. ${ }^{13}$ Nevertheless, one can say that the divergence in policies was to a certain extent mitigated by indirect Community-wide measures, such as the introduction of mandatory targets of RE shares for Member States and regulation on permissible forms of state aid. Harmonization in RE policies within the EU is subject to contentious debate. The elimination of distortions on the European market of RE, increased popularity of RE technologies and reduced costs for consumers due to competition between producers, are all named among the advantages of harmonization. ${ }^{14}$ Critical remarks include a potential rise in the price of support measures and disruptive effects on the RE industry caused by unpredictable regulatory changes at both the EU and Member State levels. ${ }^{15}$

\footnotetext{
${ }^{10}$ Jacobs 25-36.

${ }^{11}$ Ibid.

${ }^{12}$ Directive (EC) 2009/28/EC, Article 23.8.

${ }^{13}$ Catherine Banet, Tradable green certificates schemes under EU law (Faculty of Law, University of Oslo 2012) 108.

${ }^{14}$ Jacobs 36-37.

${ }^{15}$ Ibid 38.
} 
The avalanche of PV solar ITA cases seems to exploit the latter fears. What is striking here is that these adverse effects came into reality even without centralized harmonization through indirect management ${ }^{16}$ by the EU.

The current situation where RE policies are being actively promoted by the EU, while at the same time Member States are finding themselves subject to a number of ITA disputes in relation to these same policies is undermining the legitimacy of the EU as supranational institution. One of the contemporary critiques of multilevel regulation is the impossibility to determine which level of regulation is responsible for a particular policy decision. ${ }^{17}$ Clear allocation and use of competences has been suggested ${ }^{18}$ as an efficient means of combating the deficit of EU legitimacy, and there is some indication that the EU is moving in this direction.

Furthermore, a brief comment on the suggested policy framework in the period from 2020 to 2030 is necessary. ${ }^{19}$ The Commission has signaled its intent to abolish mandatory national targets in favor of single target for the whole EU, which should be collectively gained by all Member States. ${ }^{20}$ This approach is deemed to provide greater flexibility to Member States in designing their renewable policies. Nevertheless, the Commission wants to maintain a "strong European governance framework" 21 through guidance and monitoring procedures over national plans and commitments, which shall become operational before 2020 in order to guide Member States and encourage investors. ${ }^{22}$ It seems reasonable to expect that the joint planning process between the Commission and the Member States, followed by the Commission's review of national plans, will likely help to increase harmo-

\footnotetext{
${ }^{16}$ Ibid 201.

${ }^{17}$ Andreas Føllesdal, 'Epilogue: toward More Legitimate Multilevel Regulation' in Andreas Føllesdal, Ramses A. Wessel and Jan Wouters (eds), Multilevel Regulation and the EU (Martinus Nijhoff Publishers 2008) 390 .

${ }^{18}$ Ibid 394-396.

${ }^{19}$ Communication from the Commission COM/2014/015 A policy framework for climate and energy in the period from 2020 to 2030 [2014].

${ }^{20}$ Ibid 6.

${ }^{21}$ Ibid 5.

${ }^{22}$ Ibid 12-13.
} 
nization between national support schemes, and reduce risks of abrupt regulatory policy changes.

\subsubsection{Staid aid debate}

As a general rule, state aid is incompatible with the internal market of the EU. ${ }^{23}$ Exceptions include cases, when such aid is recognized as permissible by the European Council (Council) on the proposal of the Commission. ${ }^{24}$ In any case, the Commission should be informed about state aid schemes adopted by each Member State in order to determine their compatibility with the internal market. $^{25}$

With regard to PV solar support schemes, Member States face two different options. ${ }^{26}$ In one case, the financial burden of support to RE producers is distributed among all energy consumers (the ratepayer option); while in other it is financed from state revenue (the taxpayer option). It has been said ${ }^{27}$ that in the former case Member States have less risks to conflict with state aid rules, as there is no allocation of public funds by any public body.

The increased use of $\mathrm{RE}^{28}$ is part of the Community's environmental priority in providing more flexibility for Member States experimenting with state aid to promote RE production. Member States frequently refer to the Guidelines in their notifications to the Commission. In response, the Commission generally has supported suggested support schemes without any objection. $^{29}$

\footnotetext{
${ }^{23}$ Consolidated version of the Treaty on the Functioning of the European Union [2012], Article 107(1).

${ }^{24}$ Ibid, Article 107(3)(e).

${ }^{25}$ Ibid, Article 108(3).

${ }^{26}$ Jacobs 82-83; Mark Fulton and others, 'GET FiT Program: Global Energy Transfer Feed-In Tariffs for Developing Countries' (DB Climate Change Advisors, Deutsche Bank Group, 2010) <https://institutional.deutscheawm.com/content/_media/GET_FIT_-_042610_FINAL.pdf> accessed 10.11.2015.

${ }^{27}$ Jacobs 89-90.

${ }^{28}$ Community guidelines on State aid for environmental protection [2008] OJ C 82, 1.4.2008, § 48.

${ }^{29}$ See e.g. ; Communication from the Commission State aid SA.31236 (2011/N) - Ireland [2011] JOCE C/312/2012; Communication from the Commission State aid SA.35177 (2014/NN) - Czech Republic [2014] JOCE C/280/2014.
} 
Moreover, the Commission signals its willingness to control national RE policies through the state aid mechanism. For example, in its recent Guidelines ${ }^{30}$ the Commission shifted preference from FITs to market premiums in the search of less market distortive means of state aid. In the long term perspective, the Commission wants to abandon subsidies for 'mature' RE technologies, allowing market distortive measures only for new and underdeveloped ones. ${ }^{31}$ This approach coincides with many national support schemes, which prioritize 'innovative' investments with modern technologies. However, it is not entirely clear yet how the 'maturity' of technology will be determined in the Commission's proposal, and whether this requirement will be framed in absolute terms or in comparison to market competitors.

In the context of RE investment disputes, compliance with state aid requirements can be used as an argument for state defense. ${ }^{32}$ The illegality of a state aid scheme (for example, due to the lack of prior notifications to the Commission) may influence an investor's standing in the proceedings. A recent study concludes ${ }^{33}$ that such argumentation would be not be recognized by an investment arbitration tribunal, except for the case when the investor was reasonably aware of the illegality of state aid. In this case, it would be hard to conclude that the investor's expectations were legitimate.

\subsection{PV solar investment claims and EU investment treaties}

The investment treaty regime within the EU can be structured into two types of treaties: (i) the Energy Charter Treaty (ECT); and (i) intra-EU bilateral investment treaties (BITs) signed by two Member States. Both types of treaties provide the legal basis for many of the

${ }^{30}$ Communication from the Commission Guidelines on State aid for environmental protection and energy 2014-2020 [2014] OJ C 200, 124.

${ }^{31}$ Communication from the Commission COM/2014/015 9.

32 Alexander Reuter, 'Retroactive Reduction of Support for Renewable Energy and Investment Treaty Protection from the Perspective of Shareholders and Lenders' (2015) 12 Transnational Dispute Management, $34-41$

${ }^{33}$ Ibid 41 . 
PV solar ITAs, and therefore require a consistent approach from the EU. ${ }^{34}$ In the following section, the implications of these regimes for the EU and its Member States in the context of RE investment disputes will be considered.

\subsubsection{The Energy Charter Treaty}

The ECT is an international treaty with a predominantly European scope of application, which was adopted for the facilitation of energy cooperation between Eastern and Western European states. ${ }^{35}$ The application of the ECT in investment cases initially remained rather modest. As one prominent scholar reflected in $2010,{ }^{36}$ the limited number of cases did not even allow identifying trends in the application of the treaty. However, the predicted ${ }^{37}$ 'steady stream of cases' due to rising investor awareness of the treaty protection available under the ECT is being demonstrated by the PV solar cases. As reported, ${ }^{38}$ in the last three years, the number of cases filed under the ECT has doubled, largely due to the PV solar claims against Spain and the Czech Republic.

Although the scope of the treaty is limited to the energy sector, ${ }^{39}$ it was adopted before the promotion of low-carbon investment appeared predominately on the political agenda (in other words, it has a "pre-Kyoto" character). ${ }^{40}$ It therefore seems questionable the ECT is well-suited for the types of RE investments at disputes in the PV solar cases.

${ }^{34}$ Jan Kleinheisterkamp, 'The next 10 year ECT investment arbitration: a vision for the future-from a European law perspective' LSE Law, Society and Economy Working Papers, 14-16 <https://www.lse.ac.uk/collections/law/wps/WPS2011-07_Kleinheisterkamp.pdf> accessed 11.11.2015.

${ }^{35}$ Kaj Hobér, 'Investment Arbitration and the Energy Charter Treaty' (2010) 1 Journal of International Dispute Settlement 153-190, 154.

${ }^{36}$ Ibid 168-169.

${ }^{37}$ Ibid 190.

38 Crina Baltag, 'What's New with the Energy Charter Treaty?' (Kluwer Arbitration Blog, 2015) $<$ http://kluwerarbitrationblog.com/blog/2015/06/13/whats-new-with-the-energy-charter-

treaty/?utm_source=feedburner\&utm_medium=email\&utm_campaign=Feed $\% 3 \mathrm{~A}+$ KluwerArbitrationBlogFul 1+\%28Kluwer+Arbitration+Blog+-+Latest+Entries\%29> accessed 31.07.2015.

${ }^{39}$ Hobér 155.

${ }^{40}$ Peter Cameron, 'The Energy Charter Treaty Provisions On Low Carbon Investment' (Energy Charter Secretariat, 2012) $\quad 10 \quad<$ http://www.encharter.org/fileadmin/user_upload/Publications/LowCarbon_Investment_2013.pdf> accessed 02.08.2015. 
Another interesting question is the applicability of the ECT to intra-EU investment disputes. The Commission is reportedly taking a strongly negative approach, declaring that the ECT contains an 'implicit disconnection clause,' which would deprive Member States from the dispute settlement provisions in the ECT after their accession to the EU. ${ }^{41}$ However, as evidenced in the recent $E D F$ case, ${ }^{42}$ this position does not find support from arbitrators ${ }^{43}$ or domestic courts. ${ }^{44}$ In this matter one can only agree with the majority and reiterate that such serious questions as non-application of the treaty should be expressed in clear and unambiguous terms (especially with regard to the ECT, whose provisional application in the series of Yukos cases has eventually led to the biggest award in the history of investment arbitration $^{45}$ ).

\subsubsection{The intra-EU Bilateral Investment Treaties}

With the adoption of the Lisbon Treaty, foreign direct investment (FDI) was included in the Common Commercial Policy of the EU; ${ }^{46}$ the European Parliament and the Council were

${ }^{41}$ Luke Eric Peterson, 'Investigation: In Recent Briefs, European Commission Casts Doubt on Application of Energy Charter Treaty to Any Intra-EU Dispute' (IAReporter, 2014) $<$ http://www.iareporter.com/articles/investigation-in-recent-briefs-european-commission-casts-doubt-onapplication-of-energy-charter-treaty-to-any-intra-eu-dispute/> accessed 10.11.2015; Luke Eric Peterson, 'Brussels' Latest Intervention Casts Shadow over Investment Treaty Arbitrations Brought by Jilted Solar Energy Investors' (IAReporter, 2014) <http://www.iareporter.com/articles/brussels-latest-intervention-castsshadow-over-investment-treaty-arbitrations-brought-by-jilted-solar-energy-investors/> accessed 10.11.2015.

${ }^{42}$ EDF International S.A. v. Republic of Hungary [2014] (Tribunal ad hoc 04.12.2014).

${ }^{43}$ Luke Eric Peterson, 'Intra-EU Treaty Claims Controversy: New Decisions and Developments in Claims Brought by EU Investors vs. Spain and Hungary' (IAReporter, 2014) $<\mathrm{http}: / / \mathrm{www}$.iareporter.com/articles/intra-eu-treaty-claims-controversy-new-decisions-and-developments-inclaims-brought-by-eu-investors-vs-spain-and-hungary/> accessed 08.08.2015.

${ }^{44}$ Arrêt 4A_34/2015 du 6 octobre 2015, Cour de droit civil [2015] (Tribunal Fédéral Suisse 06.10.2015); see also Jarrod Hepburn, 'In Upholding Intra-EU Energy Charter Award, Swiss Court Considers EU State Aid Issue, as Well as Umbrella Clause Reservation and Tribunal's Damages Methodology' (IAReporter, 2015) $<\mathrm{http}: / /$ www.iareporter.com/articles/in-upholding-intra-eu-energy-charter-award-swiss-court-considers-eustate-aid-issue-as-well-as-umbrella-clause-reservation-and-tribunals-damages-methodology/> accessed 10.11.2015.

${ }^{45}$ Martin Dietrich Brauch, 'Yukos v. Russia: Issues and legal reasoning behind US\$50 billion awards' (IISD, 2014) <https://www.iisd.org/itn/2014/09/04/yukos-v-russia-issues-and-legal-reasoning-behind-us50-billionawards/> accessed 24.11.2015

${ }^{46}$ Treaty of Lisbon amending the Treaty on European Union and the Treaty establishing the European Community [2007], § 158. 
empowered to define its framework of implementation. The question has arisen with regard to investment treaties, previously concluded by the Member States.

These treaties can be logically divided into two categories: BITs of EU Member States with third states (extra-EU BITs) and between themselves (intra-EU BITs). The latter were especially problematic as during the last decade the Commission has not reached an agreement with Member States concerning their validity under the EU legal regime. ${ }^{47}$

Fearing the due respect and the possibility that the supremacy of EU law doctrine might be challenged by arbitral tribunals, the Commission has intervened in a number of intra-EU BIT investment disputes. In all cases the arbitral tribunals were reluctant to recognize intraEU BITs as implicitly terminated. In the Eastern Sugar case, ${ }^{48}$ the Tribunal refused to accept arguments about automatic or implicit supersession of BIT by the EU legal order. In the Eureko case, ${ }^{49}$ the Tribunal rejected all objections to jurisdiction, relating to EU accession (termination of BIT due to the conclusion of subsequent treaty; inapplicability of the BIT due to the application of successive treaty with conflicting provisions, or due to the 'interpretative monopoly' of the Court of Justice of the European Union (CJEU) over the dispute). The legal doctrine also regards intra-EU BITs as unaffected by accession, remarking that Member States are nevertheless precluded from signing new intra-BITs. ${ }^{50}$

The discussion over intra-EU BITs brings us back to the requirements of permissible state aid. Intervening as amicus curiae in the Micula case ${ }^{51}$ the Commission submitted that the arbitral award under intra-BIT is likely to result in state aid in violation of Community

\footnotetext{
${ }^{47}$ Wenhua Shan and Sheng Zhang, 'The Treaty of Lisbon: Half Way toward a Common Investment Policy' (2010) 21 European Journal of International Law 1049-1073, 1054-1056.

${ }^{48}$ Eastern Sugar B.V.(Netherlands) v. The Czech Republic [2007] Partial Award (SCC Case No. 088/2004 27.03.2007) 32-39.

${ }^{49}$ Achmea B.V. v. The Slovak Republic (formerly Eureko B.V. v. The Slovak Republic) [2010] Award on Jurisdiction, Arbitrability and Suspension (PCA Case No. 2008-13 26.10.2010) 60-75.

${ }^{50}$ Shan and Zhang 1068.

${ }^{51}$ Ioan Micula, Viorel Micula, S.C. European Food S.A, S.C. Starmill S.R.L. and S.C. Multipack S.R.L. v. Romania [2013] Final Award (ICSID Case No. ARB/05/20 11.12.2013).
} 
rules. ${ }^{52}$ The Tribunal rejected the argument, declaring that the enforcement matters fall beyond its scope of application. ${ }^{53}$ Similar arguments were presented by the Commission in the US Steel case, ${ }^{54}$ which was eventually discontinued due to the withdrawal of claim. As was reported back in 2010, ${ }^{55}$ the Commission was persuading Member States to terminate intra-EU BITs either with immediate ending, or with a prolonged phase-out period. This proposal was not unanimously supported. In June 2015 the Commission initiated ${ }^{56}$ infringement procedures against a handful of states (Austria, the Netherlands, Romania, Slovakia and Sweden) requesting that they terminate their intra-EU BITs. As ground for termination, the Commission mentioned an "overlap and conflict with EU single market on cross-border investment," which brings "very practical consequences" of increasing number of investment arbitration claims. ${ }^{57}$ As an example of a particularly distortive claim, the press release referred to the aforementioned Micula case, where the tribunal "ignored the Commission's position that such an award would infringe EU state aid rules." ${ }^{\text {"58 }}$ The Commission also indicated that administrative procedures would be initiated against the remaining 21 Member States, and praised two states (Ireland and Italy) which had already terminated their intra-EU BITs. 59

Furthermore, Member States themselves exercise regulatory avoidance of potential PV solar claims through the termination of BITs. For example, starting from 2011 Czech Re-

\footnotetext{
${ }^{52}$ Ibid, $\S \S 334-336$. See also subsequent correspondence on the implementation of the award: Communication from the Commission on State aid SA.38517(2014/C) (ex 2014/NN) - Romania [2014] OJ L 232; Commission Decision (EU) 2015/1470 [2015] OJ L 232.

${ }^{53}$ Micula v Romania (Award), § 340.

${ }^{54}$ Communication from the Commission Ref. Ares(2014)1576095 - 16/05/2014 Amicus Curiae Brief In PCA case No. 2013-6 (Arbitration under the 1976 UNCITRAL Arbitration Rules) U.S. Steel Global Holdings I B.V. (The Netherlands) [2014].

${ }^{55}$ Luke Eric Peterson, 'EC Asks Member-States to Signal by Year's End Whether They Will Terminate Their Intra-EU Investment Treaties; Spectre of Legal Action Looms' (IAReporter, 2010) $<$ http://www.iareporter.com/articles/ec-asks-member-states-to-signal-by-years-end-whether-they-willterminate-their-intra-eu-investment-treaties-spectre-of-legal-action-looms/> accessed 12.11.2015.

56 'Commission asks Member States to terminate their intra-EU bilateral investment treaties' (European Commission, 2015) <http://europa.eu/rapid/press-release_IP-15-5198_en.htm> accessed 11.11.2015.

${ }^{57}$ Ibid.

${ }^{58}$ Ibid.

${ }^{59}$ Ibid.
} 
public has been reportedly preparing for its PV solar investment cases by reviewing all of its BITs. ${ }^{60}$

\section{Chapter conclusions}

The introduction of support schemes for RE was promoted to Member States from the EU level. Nevertheless, due to failed harmonization attempts, the EU has had little or no direct influence on the overall design of national support schemes. The process of harmonization was conducted only through indirect mechanisms, such as the EU requirements of permissible state aid. The Commission requires Member States to report on their RE incentivization programs, and can sanction them in cases of non-compliance. The legality of RE support schemes is thus determined by the Commission. However, from the prospective of ITA, Member States are solely responsible for their RE policies, as promoted through a 'bottom-up' approach. This situation has led to a gap between supranational governance and control, from one side, and responsibility and accountability, from the other side, and potentially undermines the legitimacy of the EU.

The Commission also actively participates in discussions on the validity of intra-EU BITs. The termination of intra-EU BITs is requested by the Commission, while the powers to conclude and terminate such treaties are still preserved for Member States. The Commission insists on the inapplicability of the ECT and intra-EU BITs due a number of reasons, and it is unclear to what extent arbitral tribunals should follow the Commission's reasoning. The greatest risk for the EU seems to be the independence of investment tribunals in interpretation and application of the EU law: one may recall that in the series of ongoing PV solar disputes, the Commission continues to apply for admission to the proceedings as a non-disputing party. ${ }^{61}$ The unclear status of intra-EU BITs, especially in regard to cases arising out of the revocation of state aid rules, leads to a high degree of uncertainty for

\footnotetext{
${ }^{60}$ Lucie Kavanova, 'Economy \& Business: Why Czech Solar Investors Feel Burned' (2011) Transitions Online, 3.

${ }^{61}$ Peterson.
} 
states and investors. A recent study ${ }^{62}$ noted the bifurcation of the Commission's behavior: investors will likely hold in distrust the Commission's promises of stable investment policy, when they are confronted with the Commission's anti-investment rhetoric in the abovementioned disputes.

Therefore, the avalanche of RE cases brings risks of legal incoherence between EU law and international investment law. It may be concluded that Member States cannot do whatever they want in relation to their RE support schemes. They are being guided by the Commission, who is interfering both in regard to how states incentivize RE, but also in how Member States are supposed to respond to intra-EU BIT cases filed against them. Facing this crisis on the EU level, one may find it useful to descend on the national level in order to see what policies triggered the avalanche; and it is upon these issues that this thesis now turns.

\footnotetext{
${ }^{62}$ Daniel Behn, Ole Kristian Fauchald and Laura Letourneau-Tremblay, 'Promoting Renewable Energy in the EU: Shifting Trends in Member State Policy Space’ (2015 forthcoming) European Business Law Review.
} 


\section{Case study: Renewable investment policies in EU Member States}

Following the promotion both on the international and the EU levels, states started to adopt RE incentivization policies to attract investors. Their legislation developed through the enforcement of Directives, being characterized as an "EU-induced matrix." tives offered to date have included certain lucrative promises of stable support for energy producers for a considerable period of time (i.e., through FITs). Maintaining these incentives for some Member States has become difficult. At a certain turning point the increased amount of support measures became either devastating for the state budget or unbearably high for consumers. However, the adopted mitigating policies have run counter to investor's expectations protected under investment treaties and are currently being challenged before different ITA tribunals.

Four states have been selected for the case study. The first one is Germany, which was a pioneer in RE promotion, and has managed to regulate RE support schemes fairly smoothly without any known ITA claims. Three other examples (Spain, Italy and the Czech Republic) are the states that have attracted the majority of the disputes to date. The policies of all four states are worth comparing in order to identify their implications on investment cases and justify this difference in the number of ITA claims each state has attracted.

\subsection{Germany}

Being traditionally cautious about risky nuclear energy, Germany eventually became the major promoter of RE in Europe. The regulation of support schemes for RE investments has come a long way from their beginnings in the early 1990's, and to date seems to be the most developed in Europe.

In 1991, Germany adopted the Electricity Feed-In Law (Stromeinspeisungsgesetz), ${ }^{64}$ which obliged electricity suppliers to purchase the energy produced from RE sources with a cer-

\footnotetext{
${ }^{63}$ Zuzanna Brocka-Balbi, 'The Rise and Fall of the Italian Scheme of Support for Renewable Energy From Photovoltaic Plants' (2015) 12 Transnational Dispute Management, 4.

${ }^{64}$ Gesetz über die Einspeisung von Strom aus erneuerbaren Energien in das öffentliche Netz [Law on feeding electricity from renewable energy sources into the public grid], 07.12.1990, BGB1. 1990 I S. 2633.
} 
tain amount of remuneration. The law was further amended in $1998 .^{65}$ The lack of notification to the Commission concerning these amendments resulted in the notorious PreussenElektra case before the ECJ, ${ }^{66}$ where the Court declared that the provisions obliging private entities to purchase RE under non-market conditions did not violate Community law on state aid. ${ }^{67}$ Moreover, the Court specifically underlined the public importance of RE production for the Community's goals of environmental protection and combating climate change. ${ }^{68}$ Since then, Germany has expressed a cautious approach towards state aid rules, which is preserved till the present day. ${ }^{69}$

The next milestone appeared in 2000 with the adoption of the Renewable Energy Sources Act (Erneuerbare-Energien-Gesetz, EEG). ${ }^{70}$ The minimal FIT was adopted in the amount of $45,7 €$ cent/kWh (kilowatt per hour). ${ }^{71}$ The incentives were promised for new installations for a period of 20 years, and for existing installations starting from the year $2000 .^{72}$ Thus, it is worth noting that positive effects of the Act applied with retroactive force for the period of three months for the projects installed before its adoption. The tariff review procedure was envisaged for every two years. ${ }^{73}$

Four years later, a new law $^{74}$ was adopted in response to Directive 2001/77/EC. The law included a number of new provisions: (i) the obligation of priority access to the grid, (ii) requirements of transparency in remuneration process, (iii) guarantees of origin and (iv) a

${ }^{65}$ Gesetz zur Neuregelung des Energiewirtschaftsrechts [New law for the energy industry], 24.04.1998, BGB1. 1998 I S. 730.

${ }^{66}$ Case C-379/98 PreussenElektra AG v Schhleswag AG [2001] (ECJ 13.03.2001).

${ }^{67}$ Ibid, $\S 66$.

${ }^{68}$ Ibid, $\S \S 72-77$.

${ }^{69}$ For example, recently Germany requested a confirmation from the EU that the change in incentive schemes does not constitute state aid. See 'Öffentlichkeitsbeteiligung zur EEG-Novelle stößt auf großes Interesse' (Bundesministerium für Wirtschaft und Energie, 2014) <http://bmwi.de/DE/Themen/Energie/ErneuerbareEnergien/EEG-2014/stellungnahmen-erste-runde.html> accessed 10.10.2015.

${ }^{70}$ Gesetz für den Vorrang Erneuerbarer Energien [Renewable Energy Sources Act 2000], 29.03.2000, BGB1 I S. 305 .

${ }^{71}$ Ibid, Article 8(1).

${ }^{72}$ Ibid, Article 9.

${ }^{73}$ Ibid, Article 12.

${ }^{74}$ Erneuerbares Energien Gesetz 2004 (EEG 2004) [Renewable Energy Sources Act 2004], 21.07.2004, BGBI. I S. 1918. 
ban on double marketing of energy. The law envisaged a four year review procedure ${ }^{75}$ and preserved application of previous law for installations brought before 2000 and $2004 .^{76}$ Adopted in 2008, a new piece of legislation (EEG 2009) ${ }^{77}$ played a vital regulatory role by timely responding to the boost in PV solar investments. Amendments included the positive obligation of network operators to adjust the network capacity to the amount of supply, ${ }^{78}$ the gradual annual reduction of tariff rates and bonuses for new installations, ${ }^{79}$ as well as, a lower default rate of $21,1 €$ cent/kWh for PV solar projects. ${ }^{80}$

The cost-cutting of solar panels was reflected in the 2010 amendment to the law, ${ }^{81}$ which increased the reductions of tariff rates for new solar projects. The latter amendment was challenged in the German Constitutional Court as being contrary to investor's legitimate expectations. ${ }^{82}$ The Court rejected the appeal, stressing that the retrospective amendments were necessary in order to maintain the regulatory freedom of the legislator to adopt legal systems for new circumstances. ${ }^{83}$

EEG 2009 was substantially reviewed in $2012 .{ }^{84}$ It contained further reductions for prospective solar installations (e.g. lack of support for installations on conservation areas ${ }^{85}$ ). After less than a year, a new amendment dealing specifically with PV solar investments was introduced (the $P V$ Novelle). ${ }^{86}$ The law introduced a capacity corridor for prospective

\footnotetext{
${ }^{75}$ Ibid, Article 20.

${ }^{76}$ Ibid, Article 21(1)(7-8).

${ }^{77}$ Erneuerbares Energien Gesetz 2009 (EEG 2009) [Renewable Energy Sources Act 2009], 25.10.2008, BGB1. I S. 2074.

${ }^{78}$ Ibid, Article 9.

${ }^{79}$ Ibid, Article 20.

${ }^{80}$ Ibid, Article 32(1).

${ }^{81}$ Erstes Gesetz zur Änderung des Erneuerbare-Energien-Gesetzes [First law amending the Renewable Energy Sources Act 2009], 11.08.2010, BGB1. I S. 1170.

${ }^{82}$ Beschluss 1 BvQ 28/10 [2010] (Bundesverfassungsgericht 23.09.2010).

${ }^{83} \mathrm{Ibid}, \S 34$.

${ }^{84}$ Erneuerbare-Energien-Gesetz 2012 (EEG 2012) [Renewable Energy Sources Act 2012], 28.07.2011, BGB1. I S. 1634.

${ }^{85}$ Ibid, Article 32(2).

${ }^{86}$ Gesetz zur Änderung des Rechtsrahmens für Strom aus solarer Strahlungsenergie und zu weiteren Änderungen im Recht der erneuerbaren Energien [Law amending the legal framework for Electricity from solar radiation energy and further amendments in the Renewable Energy Sources Act, "PV novelle"], 17.08.2012, BGB1. I S. 1754.
} 
subsidized PV solar investments between 2500 and 3500 MW (megawatts) per calendar year. ${ }^{87} \mathrm{New}$ installments needed to enter the corridor in order to claim state support. The Federal Network Agency (Bundesnetzagentur) was held responsible for monthly updates on newly installed PV solar capacity as well as the total current capacity on its website. ${ }^{88}$ Further tariff rate reductions depended ${ }^{89}$ on the published capacity: the less capacity was left, the bigger the reductions. The law also provided a cap on total produced energy ${ }^{90}$ in the amount of $52000 \mathrm{MW}$, which precluded further incentives for new projects once reached. All that helped to keep investors updated about the available state support, and avoid unrealistic promises.

The default tariff rate for PV solar investments was further lowered to $13,5 €$ cent $/ \mathrm{kWh}$ and covered only big investments (with capacity equal or higher $10 \mathrm{MW}$ ). ${ }^{91}$ The PV Novelle was set retroactively applicable to investments installed as of 1 April 2012, provided that their commissioning had not yet been completed. ${ }^{92}$ This retroactive application was not surprising for the market, which was aware of these negotiations in the German Parliament. $^{93}$

The latest amendment to the Renewable Energy Sources Act was adopted in July 2014. ${ }^{94}$ The gradual monthly reductions of tariff rates were firmly tied to the amount of available capacity in the corridor (which was set between 2,4 and 2,6 MW per year). ${ }^{95}$ Tariffs for new installations were reduced by 0,5 percent on a monthly basis, with their review in comparison to the available capacity every three months. It is worth mentioning that the amendments were adopted after two rounds of public consultations, and the positions of

\footnotetext{
${ }^{87}$ Ibid, Article 1(7).

${ }^{88}$ Ibid.

${ }^{89}$ Ibid.

${ }^{90}$ Ibid.

${ }^{91}$ Ibid, Article 1(11).

${ }^{92}$ Ibid, Article 1(24)(f).

${ }^{93}$ Mark Fulton, Reid Capalino and Josef Auer, 'The German Feed-in Tariff: Recent Policy Changes' (Deutsche Bank Research, 2012) 18, footnote 48 <https://goo.gl/IVtCPL> accessed 30.09.2015.

${ }^{94}$ Gesetz für den Ausbau erneuerbarer Energien (Erneuerbare-Energien-Gesetz - EEG 2014) [Act on the Development of Renewable Energy Sources, Renewable Energy Sources Act - RES Act 2014], 21.07.2014, BGB1. I S. 1066.

${ }^{95}$ Ibid, Article 31.
} 
stakeholders were published on the web. ${ }^{96}$ Moreover, the scheme received positive response from the Commission and was declared compatible with the internal market. ${ }^{97}$

\subsection{Spain}

The majority of current PV solar investment claims are filed against Spain. ${ }^{98}$ This influx was likely caused by the inflexible regulation and overestimation of incentive capabilities. While the line of regulatory acts is impressive, it may be noted that only a few initial acts were aimed at the promotion of RE investments. All subsequent legislative and regulatory acts adopted by Spain were targeted at mitigating or scaling back the original incentives on offer and it is the consequences of these regulatory changes that form the basis for all of the ITA claims against Spain.

One of the earliest Spanish laws dealing with RE investments was adopted in $1997 .{ }^{99}$ The law prescribed $^{100}$ that electricity tariffs should be established by Royal Decree and reviewed annually. All producers of electricity were subject ${ }^{101}$ to mandatory registration and authorization (in later decrees this provision was stressed for RE producers). The latter fell under the 'special regime' (régimen especial) and permitted special remuneration for RE supplied to the grid. ${ }^{102}$ The remuneration was established in the form of a feed-in premium (FIP) - an additional payment within the pre-defined tariff rates for the surplus energy received from RE sources. A specific arrangement ${ }^{103}$ was introduced for PV solar energy, in relation to which the Government was authorized to increase FIPs beyond the statutory

96 ‘Öffentlichkeitsbeteiligung zur EEG-Novelle stößt auf großes Interesse'; 'Zweite Anhörungsrunde zur EEG-Novelle: Stellungnahmen zum überarbeiteten Gesetzentwurf' (Bundesministerium für Wirtschaft und Energie, 2014) <http://bmwi.de/DE/Themen/Energie/Erneuerbare-Energien/EEG-2014/stellungnahmenzweite-runde.html> accessed 10.10.2015.

97 'Gabriel: Brüssel gibt grünes Licht für das EEG' (Bundesministerium für Wirtschaft und Energie, 2014) <http://www.bmwi.de/DE/Presse/pressemitteilungen,did=647364.html> accessed 10.10.2015; 'Öffentlichkeitsbeteiligung zur EEG-Novelle stößt auf großes Interesse'.

${ }^{98}$ As of 22 November 2015, 27 out of 39 known cases are lodged against Spain.

${ }^{99}$ Ley 54/1997, 27.11.2997, BOE-A-1997-25340.

${ }^{100}$ Ibid, Article 17(2).

${ }^{101}$ Ibid, Article 21.

102 Ibid, Articles 27, 30.

${ }^{103}$ Ibid, Article 30(4). 
limits. Nevertheless the law authorized the Government to limit the supply from RE sources in exceptional circumstances "when the power supply conditions so require."104 A 2004 Decree $^{105}$ introduced significant positive amendments to the incentive scheme. Two mechanisms of remuneration ${ }^{106}$ were adopted at the discretion of the RE installation operator: (i) a set FIT or (ii) incentivized distribution at the market price. The incentives consisted of a bonus for market participation and a FIP, both indicated in percentage of the established statutory tariff rate. ${ }^{107}$ With regard to PV solar investments, the Decree differentiated installations by their power capacity and promised higher tariff rate for the first 25 years from the moment of launch and slightly reduced rates thereafter. ${ }^{108}$ Larger installations were also incentivized by FIPs and market bonuses.

The 2004 Decree provided stable guarantees for revision procedures. ${ }^{109}$ The rates were suggested to be reviewed every four years from 2006. Retroactive reduction for existing projects was expressly prohibited. The revised tariffs should have been adopted by Royal Decrees before the end of the year preceding their entry into force. It may be concluded that the 2004 Decree maintained investors' expectations on a high level, and gave no doubts for adverse consequences for those who already came on the market.

Nevertheless, in 2007 the Decree was replaced by an even more lucrative and investorpromising one. ${ }^{110}$ The main features of the new Decree included: (i) a shift from FIPs to fixed FIT rates (maintaining the premiums turned out to be too expensive for the Government ${ }^{111}$ ); and (ii) a high capacity target of $371 \mathrm{MW}^{112}$ for PV generation up to the next revision in 2010. With the installation of 85 percent of the projected target, the surplus remu-

\footnotetext{
${ }^{104}$ Ibid, Article 30(2). The original expression in Spanish: "cuando las condiciones del suministro eléctrico lo hagan necesario".

${ }^{105}$ Real Decreto 436/2004 [Decree 436/2004], 12.03.2004, BOE-A-2004-5562.

${ }^{106}$ Ibid, Article 22(1).

107 Ibid, Preamble, $§ 7$.

${ }^{108}$ Ibid, Article 33(1)-(2).

${ }^{109}$ Ibid, Article 40.

${ }^{110}$ Real Decreto 661/2007 [Decree 661/2007], 25.05.2007, BOE-A-2007-10556.

111 Pablo del Río and Pere Mir-Artigues, 'A Cautionary Tale: Spain's solar PV investment bubble'

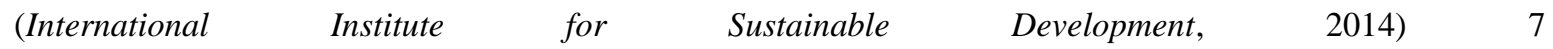
<http://www.iisd.org/gsi/sites/default/files/rens_ct_spain.pdf> accessed 02.10.2015.

112 Decree 661/2007, Article 37.
} 
neration for new projects was frozen for the length of a certain transitional period, necessary for the introduction of new capacity targets. ${ }^{113}$

The FIT rates for PV solar projects ${ }^{114}$ did not change significantly, providing $44 €$ cent/kWh in their highest (for small projects, with capacity equal or less than $100 \mathrm{~kW}$ ), and 20 percent lower rates for the lifetime of project after initial 25 year period. The exception was made for the middle-size projects (with capacity between $100 \mathrm{~kW}$ and $10 \mathrm{MW}$ ), where remuneration increased by more than 82 percent. ${ }^{115}$

According to statistics, ${ }^{116}$ the lucrative incentives of the 2007 Decree led to the boom in PV solar investment. The annual installed PV solar capacity increased five and 26 times in years 2007 and 2008 respectively in comparison to the pre-amendment year of 2006. In 2009 the capacity dropped to zero, and revived to modest levels thereafter. It follows that the dramatic increase in PV solar installations occurred during a few short months (several times the monthly installation rates exceeded $500 \mathrm{MW}$ ).

The mitigation measures came only 1,5 years after with the adoption of a 2008 Decree. ${ }^{117}$ Its preamble explained that due to the unexpected high growth in the PV solar sector, the 85 percent threshold of capacity planned for 2010 was apparently reached in less than three months. Furthermore, the 2008 Decree introduced two measures worth mentioning. First, the 2008 Decree introduced a pre-allocation register (registro de preasignación de retribución $)^{118}$ for new installations applying for compensation. Second, the period of remuneration was fixed at 25 years after either commissioning of the project or inclusion in the register. ${ }^{119}$ Under this 2008 Decree, new incoming PV solar investors would be put on notice that support for PV solar would only be available for a set period of time. ${ }^{120}$

\footnotetext{
${ }^{113}$ Ibid, Article 22(1).

${ }^{114}$ Ibid, Article 36, Table 3 (modified).

115 del Río and Mir-Artigues 7.

${ }^{116}$ Ibid 10-11.

${ }^{117}$ Real Decreto 1578/2008, 26.09.2008, BOE-A-2008-15595.

${ }^{118}$ Ibid, Article 4.

${ }^{119}$ Ibid, Article 11(5).

${ }^{120}$ del Río and Mir-Artigues 18.
} 
Further legislative changes came with two 2010 Decrees: $1565 / 2010^{121}$ and 14/2010. ${ }^{122}$ These Decrees lowered the FIT rates for prospective projects and with the retroactive force abandoned surplus tariff rates for installed projects starting from 26 year after the installation. ${ }^{123}$ These Decrees also extended these lower FIT rates by enlarging the guaranteed period from 25 to 28 years, ${ }^{124}$ but in doing so adopted further restricting measures as well. These Decrees also retroactively set both existing and prospective projects to regional caps on operating hours. ${ }^{125}$

Installation of new PV solar projects was effectively prevented by a 2012 Decree, ${ }^{126}$ which abandoned all forms of remuneration to them. Spectacularly, its preamble mentioned significant drop in demand for electricity and favorable weather conditions as grounds for the correction to the eligible tariff. A further law was passed in 2012, Law 15/2012, ${ }^{127}$ which adopted a seven percent tax for the production and feeding of PV solar generated electricity into the grid. The tax was imposed on all existing PV solar energy producers, and was further challenged ${ }^{128}$ before the Spanish Constitutional Court as being allegedly discriminatory to particular types of energy producers. The Court rejected the challenge appealing to the legislator's significant margin of appreciation.

A 2013 Decree Law ${ }^{129}$ changed the basis for calculations of all FITs to a more stable standard. The measure was intended to freeze the growth of FITs and could even lead to their reduction in real terms. ${ }^{130}$ A second law was passed in 2013, Decree Law 9/2013, ${ }^{131}$ which limited the internal rate of return for PV solar projects, lowering their rentability and mak-

\footnotetext{
${ }^{121}$ Real Decreto 1565/2010, 19.11.2010, BOE-A-2010-17976.

${ }^{122}$ Real Decreto-ley 14/2010, 23.12.2010, BOE-A-2010-19757.

${ }^{123}$ Decree 1565/2010, Article 1(10).

${ }^{124}$ Decree Law 14/2010, First Final Provision.

${ }^{125}$ Ibid, First Additional Provision.

${ }^{126}$ Real Decreto-ley 1/2012, 27.01.2012, BOE-A-2012-1310.

${ }^{127}$ Ley 15/2012, 27.12.2012, BOE-A-2012-15649.

${ }^{128}$ Sentencia 183/2014 [2014] BOE-A-2014-12649 293 (Tribunal Constitucional 06.11.2014).

${ }^{129}$ Real Decreto-ley 2/2013, 01.02.2013, BOE-A-2013-1117.

${ }^{130}$ del Río and Mir-Artigues 20.

${ }^{131}$ Decree Law 2/2013.
} 
ing them unprofitable. ${ }^{132}$

The new energy paradigm was introduced by the Law 24/2013 ${ }^{133}$ and the Decree 413/2014. ${ }^{134}$. These laws admitted significant progress towards Spain's climate change goals by means of RE. Nevertheless, the laws admitted the difficulties connected with the growth of PV solar installments, and abandoned the special regime for RE energy sources. The uniform regulation provided an amended support mechanism. The compensation to RE installments was accorded if the income received made it impossible to compete with conventional sources and their production costs could not be recovered without such compensation. $^{135}$

It may be concluded that the peculiarities of the Spanish regulatory regime in regard to PV solar support originated from the over-promised support measures that attracted many investors and the inability of state to reduce the rates once too many of them came in. In light of the Spanish situation, it is important to note that the domestic court system of Spain has so far been unsympathetic to PV solar investors and may be responsible for pushing them towards international dispute settlement.

\subsection{Italy}

The structural differences of the Italian energy scheme can be traced to early 1990's. Article 22 of the Law 9/1991 ${ }^{136}$ allowed the Interministerial Price Committee (Comitato interministeriale dei prezzi (CIP)) to adopt prices for RE and set the conditions for its supply. The adopted Resolution 6/1992 $2^{137}$ established a specific support mechanism: the incentives for RE were born directly by consumers. In response to the Directive 2001/77/EC, the Ital-

132 Daniel Behn and Ole Kristian Fauchald, 'Governments under Cross-fire? Renewable Energy and International Economic Tribunals’ (2015) 12 Manchester Journal of International Economic Law 117-139, 7; Blanca Díaz, 'Las renovables en operación se retribuirán según una "rentabilidad razonable" del 7,5\% en España’ (PV Magazine, 2013) <http://goo.gl/bkvvMV> accessed 03.10.2015.

${ }^{133}$ Ley 24/2013, 26.12.2013, BOE-A-2013-13645.

${ }^{134}$ Real Decreto 413/2014, 06.06.2014, BOE-A-2014-6123.

135 'Real Decreto 413/2014, de 6 de junio, por el que se regula la actividad de producción de energía eléctrica a partir de fuentes de energía renovables, cogeneración y residuos' (Hogan Lovells, 2014) <http://goo.gl/3dNGRd> accessed 03.10.2015.

${ }^{136}$ Legge No. 9, 09.01.1991, GU No. 13 del 16.01.1991.

${ }^{137}$ Provvedimento No. 6, 29.04.1992, GU n. 109 del 12.05.1992. 
ian Government adopted Legislative Decree 387/03, ${ }^{138}$ which formed the legal framework for RE sources and simplified the bureaucratic mechanisms for producers.

The regulation of PV solar projects started with the first Energy Bill (Conto Energia), adopted by the Ministry of Industrial Activities (Ministero delle attività produttive) in 2005. ${ }^{139}$ The First Conto Energia prescribed fixed tariff rates for PV solar investments (amounting to $44,5 €$ cent $/ \mathrm{kWh}$ for individuals and 44,5 to $49 €$ cent $/ \mathrm{kWh}$ for companies) for the period of 20 years. Notably, the First Conto Energia set the caps for all subsidized national energy capacity, which were increased by an amendment ${ }^{140}$ the following year.

The Second Conto Energia ${ }^{141}$ was adopted for further promotion of PV solar investments. The tariffs were guaranteed in a range between 36 and $49 €$ cent $/ \mathrm{kWh},{ }^{142}$ depending on the size and type of the installation. Additional premiums were adopted for installations with efficient use of energy. The national target for PV solar installations was set at $3000 \mathrm{MW}$ by $2016 .{ }^{143}$ It is worth mentioning that the law prescribed gradual annual reduction of tariff rates by two percent for future installations, starting from 1 January $2009 .^{144}$

At the same time, the promotion of PV solar investments also stepped down to the regional level without express authorization from centralized authorities. For example, the Italian region of Puglia adopted a law, ${ }^{145}$ which simplified the application procedure for PV solar plants with capacity up to one MW. ${ }^{146}$ Two years after the Italian Constitutional Court declared $^{147}$ this law was rendered unconstitutional as contradicting the provisions of republican law and giving unlawful preferences to investors in the Puglia region. The regional experiment was found harmful to the broader state interests and was therefore discontinued.

\footnotetext{
${ }^{138}$ Decreto legislativo No. 387, 29.12.2003, GU No. 25 del 31.01.2004.

${ }^{139}$ Decreto Ministeriale [Primo Conto Energia], 28.07.2005, GU No. 181 del 05.08.2005.

${ }^{140}$ Decreto Ministeriale, 06.02.2006, GU No. 38 del 15.02.2006.

${ }^{141}$ Decreto Ministeriale [Secondo Conto Energia], 19.02.2007, GU No. 45 del 23.02.2007.

${ }^{142}$ Ibid, Article 6.

143 Ibid, Article 12.

${ }^{144}$ Ibid, Article 6(2).

${ }^{145}$ Legge della Regione Puglia No. 31, 21.10.2008.

${ }^{146}$ Saverio Francesco Massari, 'The Italian Photovoltaic Sector in two Practical Cases: How to Create an Unfavorable Investment Climate in Renewables' (2015) 12 Transnational Dispute Management, 4.

147 Sentenza 119 [2010] (La Corte Costituzionale 22.03.2010).
} 
The Third Conto Energia ${ }^{148}$ was adopted in 2010 and signaled the beginning of decline of support schemes. The preamble to the law specifically mentioned the reduction in prices of solar panels, which happened since 2007. The national target of PV solar electricity production was set at $8000 \mathrm{MW}$ by $2020 .{ }^{149}$ Both existing and prospective installations were still promised incentives for 20 years. ${ }^{150}$ The authorized governmental body was under a duty to publish and regularly update the information of available capacity on its website. ${ }^{151}$ The Third Conto Energia was applied for only five months, and in May 2011 was substituted by the next regulation (Forth Conto Energia ${ }^{152}$ ). The scheme introduced a gradual reduction mechanism for prospective installations, with rates changed monthly starting from June 2011. ${ }^{153}$ The Forth Conto Energia also changed the focus of support towards smaller installations, which was criticized as "unjustified treatment disparity" between RE producers of different scale. ${ }^{154}$

After a year, the last incentive scheme (Fifth Conto Energia ${ }^{155}$ ) was adopted, reserving a cap amount of funds ( $€ 6,7$ billion) which could be spent annually on PV solar subsidies. The Fifth Conto Energia entered into force in the end of August 2012, and ceased to apply 30 days after this amount was exhausted in July 2013. ${ }^{156}$ Further regulatory amendments have also been implemented and seem to distract investors from PV solar sector towards other types of RE investment, and even more conventional types of energy (i.e. fossil

${ }^{148}$ Decreto Ministeriale [Terzo Conto Energia], 06.08.2010, GU No. 197 del 24.08.2010.

${ }^{149}$ Ibid, Article 3(1).

${ }^{150} \mathrm{Ibid}$, Articles 1(3) and 8(4).

${ }^{151}$ Ibid, Article 3(5).

${ }^{152}$ Decreto Ministeriale [Quarto Conto Energia], 05.05.2011, GU No. 109 del 12.05.2011.

${ }^{153}$ Ibid, Article 4 and Annex 5.

${ }^{154}$ Chiara Feliziani, 'The Impact of the EU Energy Policy on Member States' Legal Orders: State of Art and Perspectives of Renewable Energy in Italy and Great Britain' (2013) 5 Review of European Studies, 69.

${ }^{155}$ Decreto Ministeriale [Quinto Conto Energia], 05.07.2012, GU No. 159 del 10.07.2012.

${ }^{156}$ Joe Tirado, 'Renewable Energy Claims under the Energy Charter Treaty: An Overview' (2015) 12 Transnational Dispute Management, 5; 'Fifth feed-in scheme' (Gestore dei Servizi Energetici GSE) <http://www.gse.it/en/feedintariff/Photovoltaic/FifthFeed-inScheme/Pages/default.aspx> accessed 15.10.2015; 'Conto Energia: termine ultimo per l'invio delle richieste di riconoscimento degli incentivi' (Gestore dei Servizi Energetici GSE, 2013) <http://www.gse.it/it/salastampa/news/Pages/Conto-Energiatermine-ultimo-per-1\%E2\%80\%99invio-delle-richieste-di-riconoscimento-degli-incentivi.aspx $>\quad$ accessed 15.10.2015. 
fuels). ${ }^{157}$

In 2014, the situation regarding support to PV solar producers continued to deteriorate. The Decree Law 91/2014 on incentive spreading ${ }^{158}$ (spalma incentivi ${ }^{159}$ ) represented an "emergency legislative intervention" 160 relating to a significant budgetary crisis for the Italian Government. Due to its temporary application, this Decree Law was later converted into law. ${ }^{161}$ Among other cost-cutting measures, the law provides for the reduction of electricity bills for consumers ${ }^{162}$ and retroactive changes to the FIT rates for large-scale PV solar producers (with capacity of $200 \mathrm{~kW}$ and higher). ${ }^{163}$ The change allows three options for investors starting from 1 January 2015. All of them reduce the existing subsidies through different time periods and rate arrangements. The law also promises to secure investors' interests by providing bank loans in the differentiating amount between the initial rates and the recalculated ones. The loan conditions are to be established separately by Ministerial Decree, ${ }^{164}$ which was not adopted in appropriate time. ${ }^{165}$

All investors in PV solar projects in Italy were left with the choice between possible options, all of which modified retrospectively their original support schemes. ${ }^{166}$ It is needless to say that such emergency arrangements ran contrary to their expectations, based on previous legislative promises.

\footnotetext{
${ }^{157}$ Massari 11.

${ }^{158}$ Decreto-legge No. 91, 24.06.2014, GU No. 144 del 24.06.2014.

${ }^{159}$ Massari 7.

${ }^{160}$ Behn and Fauchald 126.

${ }^{161}$ Legge No. 116, GU No. 192 del 20.08.2014.

${ }^{162}$ Law 91/2014, Article 23.

${ }^{163}$ Ibid, Article 26(3).

${ }^{164}$ Ibid, Article 26(5).

${ }^{165}$ Massari 8.

${ }^{166}$ Dörte Fouquet and Jana Viktoria Nysten, 'Retroactive and retrospective changes and moratoria to RES support' (KeepOnTrack.EU, 2015)

<http://www.keepontrack.eu/contents/publicationsbiannualnationalpolicyupdatesversions/policy-briefing6retroactive-and-retrospective-changes-and-moratoria-to-res-support.pdf $>$ accessed 08.11.2015.
} 


\subsection{The Czech Republic}

The case of the Czech Republic is particularly interesting due to their accession to the EU in 2004, which resulted in the prolonged adoption of RE legislation and delayed fulfillment of national RE targets. According to early pre-accession arrangements, ${ }^{167}$ the Energy Regulatory Office (ERO) was obliged to disclose suggested electricity tariffs for public discussion.

Decree 252/2001 ${ }^{168}$ introduced an obligation for grid operators to purchase energy obtained from renewable sources on the basis of a negotiated price. The support scheme was quite moderate and did not result in increased investment. ${ }^{169}$

Law $180 / 2005^{170}$ was adopted in order to implement Directive 2001/77/EC, setting the basic conditions for RE investments. Producers were granted ${ }^{171}$ a choice between purchase prices for electric energy (FITs) and green bonuses (FIPs). The FITs were guaranteed for the period of 15 years. ${ }^{172}$ Notably, the law prescribed ${ }^{173}$ that decrease of the FIT could not be lower than 95 percent of the FIT active in the previous year (starting from the year 2007). The ERO was obliged ${ }^{174}$ to publish annual information reports on the amount of installed RE projects, their impact on consumers and progress in achieving national energy goals. Further changes of RE support scheme were adopted as amendments to the Law $180 / 2005$.

${ }^{167}$ Zákon o podmínkách podnikání a o výkonu státní správy v energetických odvětvích a o změně některých zákonů (energetický zákon) [Law on business conditions and public administration in energy sectors and amending certain laws; Energy Act 2000], 28.11.2000, 458/2000 Sb., § 17e(2)(a).

${ }^{168}$ Vyhláška č. 252/2001 Sb. Ministerstva průmyslu a obchodu ze dne 28. června 2001 o způsobu výkupu elektrriny z obnovitelných zdrojů a z kombinované výroby elektřiny a tepla [Decree No. 252/2001], 28.06.2001.

${ }^{169}$ Behn and Fauchald 123.

${ }^{170}$ Zákon o podpoře výroby elektřiny z obnovitelných zdrojů energie a o změně některých zákonů (zákon o podpoře využívání obnovitelných zdrojů) [Law 180/2005], 05.05.2005, 180/2005 Sb.

${ }^{171}$ Ibid, § 4(3).

${ }^{172}$ Ibid, § 6 .

${ }^{173}$ Ibid, § 6(4).

${ }^{174}$ Ibid, § 7 . 
The amendment Law $137 / 2010^{175}$ lifted the limits for annual price reduction under certain conditions. The Law 330/2010 ${ }^{176}$ limited access to support schemes only for existing installations starting from 1 March 2011. A new tax levy ${ }^{177}$ was introduced solely for PV solar projects which were put in operation in 2009 and 2010. The levy was set at the rate of 26 percent for FITs and 28 percent for FIPs, and was set effective between 2011 and 2013. Low-scale projects (up to $30 \mathrm{~kW}$ ) were exempted from the tax. The law also introduced ${ }^{178}$ state support for transmission system operators to cover the extra costs of RE incentives.

The retroactive application of the tax levy was challenged by a group of senators before the Czech Constitutional Court. In a 2012 decision, ${ }^{179}$ the Court extensively relied on comparative judicial practice of RE cases in European states. Discussing the levy, the Court drew the distinction between the concepts of 'true' and 'false' retroactivity. ${ }^{180}$ According to Court, 'true retroactivity' appears when the new rule changes a previously existing legal framework, while 'false retroactivity' does not change the prior framework, but modifies future legal relations arising from some past events (a simplier distinction can be made between 'retroactivity' and 'retrospectivity' and will be discussed in the next chapter). The Court concluded that the application of 'true retroactivity' was generally restricted, while its 'false' counterpart could be justified both under the Czech constitutional law and the European Convention on Human Rights, if it does not violate the legitimate expectations of investors. ${ }^{181}$ In the case of tax levy, the Court found that the tax was one of 'false retroac-

${ }^{175}$ Zákon kterým se mění zákon č. 180/2005 Sb., o podpoře výroby elektřiny z obnovitelných zdrojů energie a o změně některých zákonů (zákon o podpoře využívání obnovitelných zdrojů) [Law 137/2010], 20.05.2010, $137 / 2010 \mathrm{Sb}$.

${ }^{176}$ Zákon kterým se mění zákon č. 180/2005 Sb., o podpoře výroby elektřiny z obnovitelných zdrojů energie a o změně některých zákonů (zákon o podpoře využívání obnovitelných zdrojů), ve znění pozdějších předpisů [Law 330/2010], 30.11.2010, 330/2010 Sb.

${ }^{177}$ Zákon kterým se mění zákon č. 180/2005 Sb., o podpoře výroby elektřiny z obnovitelných zdrojů energie a o změně některých zákonů (zákon o podpoře využivání obnovitelných zdrojů), ve znění pozdějších předpisů, a některé další zákony [Law 402/2010], 28.10.2015, 402/2010 Sb., § 7a.

${ }^{178}$ Ibid, § 6a.

${ }^{179}$ Photovoltaic Power Plants [2012] Judgment (Czech Republic Constitutional Court Case No. Pl. ÚS 17/11 15.05.2012).

${ }^{180}$ Ibid, $\S 50$.

${ }^{181}$ Ibid, §§ 51-54. 
tivity'. The Court suggested taking into account the concrete economic situation in the state which preceded the adoption of the levy, ${ }^{182}$ and concluded that even despite the levy the statutory guarantees for return on investment were maintained. ${ }^{183}$ Notably, the Court also suggested that an abstract review of constitutionality may not foresee all potential situations with investments, which need to be settled by courts on an individual basis. ${ }^{184}$ In 2012, Law 180/2005 was superseded by a new law, ${ }^{185}$ which was adopted following the issuance of Directive 2009/28/EC. The law specifically mentioned withdrawal from PV solar electricity as one of its goals, ${ }^{186}$ and provided support only for low-scale rooftop installations. ${ }^{187}$ Provisions concerning the tax levy were also included in the new law. ${ }^{188}$ In the end of 2013, the tax levy was changed. ${ }^{189}$ In the new redaction, it was set at lower numbers (10 percent for FITs, and 11 percent for FIPs), but for a longer period of time: from 1 January 2014 till the end of subsidized period of a project. The change covered only those installations which became operational during the year 2010. Notably, the Law abandoned support for the majority of other prospective RE investments, ${ }^{190}$ except those which were planned to become operational before 2016.

The most recently published tariff rates ${ }^{191}$ for electricity from PV solar projects show a range of FITs and FIPs applicable to installations set before 2014. The highest amounts of these subsidies were provided for installations made between 2006 and 2011. After 2011,

${ }^{182}$ Ibid, $\S \S 65-66$.

${ }^{183}$ Ibid, $\S 68$.

${ }^{184}$ Ibid, $\S 88$.

${ }^{185}$ Zákon o podporovaných zdrojích energie a o změně některých zákonů [Law 165/2012], 30.05.2012, $165 / 2012 \mathrm{Sb}$.

${ }^{186} \mathrm{Ibid}, \S 1(1)(\mathrm{f})$.

${ }^{187}$ Ibid, § 4(5)(d).

${ }^{188}$ Ibid, $\S \S 14-22$.

${ }^{189}$ Zákon kterým se mění zákon č. 165/2012 Sb., o podporovaných zdrojích energie a o změně některých zákonů, ve znění zákona č. 407/2012 Sb., a další související zákony [Law 310/2013], 02.10.2013, 310/2013 Sb.

${ }^{190}$ Ibid, Article 2; Tirado 8.

191 'Cenové rozhodnutí Energetického regulačního úřadu č. 1/2014 ze dne 12. listopadu 2014, kterým se stanovuje podpora pro podporované zdroje energie [ERO Price Decision No. 1/2014]' (Energetický regulační úrad, 2014) <http://www.eru.cz/cs/poze/cenova-rozhodnuti> accessed 25.10.2015. 
the prices were gradually reduced, so that the latest installments can receive approximately one-seventh of the abovementioned highest amounts.

\section{Chapter conclusions}

This overview shows many similarities of states' RE policies in the PV solar sector. Initial support schemes provided high tariff rates, which were promised for the period of 15 to 25 years, and envisaged rather relaxed review procedures every four years. Previous studies ${ }^{192}$ show a certain degree of policy convergence among European states in relation to their PV solar investment support schemes. Some have suggested that this convergence successfully evolved despite failed harmonization at the EU level.

This case study views focused on the changes made to laws and regulation as a result of over-subsidization and the dramatic reduction in the costs of PV solar panels. States responded with different types of strategies to remedy the problem of over-incentivization. The policy fluctuations ultimately resulted in reduced or abandoned state support for PV solar investments and an avalanche of PV solar claims before ITA tribunals.

The German legislative history shows cautious attention towards RE policies. The novel mechanisms of regulation (such as capacity caps, energy corridors and progressive annual and monthly reductions) were early introduced for new investments, and did not undermine the position of existing investors, who were enjoying their 20 year fixed FIT rates. The regulatory system managed to conquer the 'solar bubble' and actively respond to market challenges efficiently. Furthermore, German regulatory bodies monitored the interests of stakeholders, involving their participation and ensured compliance with EU state aid rules. All these measures resulted in the status quo: to date, there are no PV solar investment claims against Germany.

The three other states in the case study have not been as efficient in responding to the 'solar bubble'. For Spain it took more than 1,5 years to implement mitigating measures, which significantly impaired the interests of investors by introducing time-limitations on promised support and a new solar tax. Similar impairments were observed in Italy and Czech

\footnotetext{
192 See the conclusions about German, Spanish and French regulation in Jacobs 97-100.
} 
Republic. Initially generous support for large PV solar farms shifted towards smaller ones, often with retroactive or retrospective effect. These states also lacked good mechanisms for limiting the amount of admitted investments; by the time they realized that too many projects had been admitted, they had no way to limit the amount of subsidies given to these entities without retrospectively or retroactively reducing the incentives initially on offer. This explains why the majority of PV solar investment cases relate to what states have done to investors that were already online and receiving the subsidy. It is the attempts to limit the subsidies for these investments that are the subject of the disputes. In all cases, the abrupt nature of deprivatory measures resulted in domestic and international claims against the state, which - to date - have found no support in domestic courts. Therefore, it was a combination of lack of forecasting, unresponsiveness to external factors, inadequate remedies in domestic courts and a lack of regulatory flexibility which has resulted in the avalanche of PV solar ITA claims.

In conclusion, a few other European states (such as Bulgaria, Romania and Greece) are currently making changes to their support schemes. It is highly probable, that if they are not careful and do not take into account aforementioned examples, they may also attract ITA cases in the future. 


\section{Facing the avalanche of renewable energy investment claims}

The policy overview shows that foreign investors in PV solar projects were deprived from the conditions which were promised to them. The deprivation was often conducted in an abrupt manner, with retroactive effect and without consultations with stakeholders. In this section, ITA will be discussed in some detail by: (i) briefly describing the universe of PV solar investment claims against EU Member States; (ii) defining the relevant standards provided in investment treaties, which may be invoked by investors; (iii) focusing on the fair and equitable treatment (FET) standard by analyzing how it could be violated in these cases; and (iv)suggesting potential explanations for the divergent and diverse number of cases filed against different states.

\subsection{The storm is coming: PV solar claims against EU Member States}

The task of monitoring PV solar investment claims today reminds the review of a battlefield. New pins on the map symbolize new claims, and their congregation forms several fronts stretched throughout the sunny south of Europe. As of mid-November 2015 there are $39 \mathrm{PV}$ solar investment cases known, and this number will continue to grow.

It shall be noted that the description of recently filed and pending cases brings one methodological limitation. In the absence of actual decisions (none of the 39 cases have reached decisions as of mid-November 2015), second-hand evidence about these cases must be relied upon: case descriptions on the websites of arbitral institutions and various news resources.

In this section, analysis of the cases will not look at the specific states; ${ }^{193}$ but will instead focus on a brief descriptive analysis of similarities between PV solar investment cases, and try to explain the differences. The graphical representation of these findings are provided in the Annex.

Beginning with the respondent side of the dispute, evidence shows that the majority of known PV solar investment claims have been filed against Spain, the Czech Republic, Italy

${ }^{193}$ See e.g. Tirado; Behn and Fauchald. 
and Bulgaria (Annex, Figure 1). Over two thirds of known claims have been filed against Spain.

Furthermore, the cases all show interesting timing similarities. The earliest known case was registered in 2011 and the latest in November 2015 (Annex, Figure 2). No cases were filed in 2012. Half of all claims were filed in 2015; and all of these are Spanish or Italian cases. Studies show, ${ }^{194}$ that the global reduction in the price of PV solar panels occurred between 2007 and 2009. The lag between these dates and the influx of cases after 2011 may be explained by the attempts of investors to exhaust local remedies before bringing disputes to ITA, prolonged negotiations or collection of evidence.

Another interesting peculiarity is the home state of investor. The largest number of claims (27 percent) has been filed by German investors, followed by companies incorporated in Luxembourg and Netherlands (23 and 13 percent, respectively; see Annex, Figure 3). It shall be noted that so-called 'postbox' companies are frequently used in the course of corporate and investment structuring, and may not reflect the original nationality of the parent company or of individual investors. With regard to PV solar investments, such examples include the RENERGY case $^{195}$ (claimant was founded by a Mexican national ${ }^{196}$ ), the CSP Equity Investment case ${ }^{197}$ (claimant is a Luxembourg subsidiary of the Spanish company Abengoa ${ }^{198}$ ) and the Masdar Solar \& Wind Cooperatief UA case ${ }^{199}$ (parent company registered in United Arab Emirates ${ }^{200}$ ).

Speaking about the legal instruments invoked by investors (Annex, Figure 4), more than two thirds of the claims are based on the ECT. The remaining one third of cases are based on the ECT and an intra-EU BIT. There are no claims based exclusively on a BIT.

${ }^{194}$ David Feldman and others, 'Photovoltaic (PV) Pricing Trends: Historical, Recent, and Near-Term Projections' (U.S. Department of Energy, 2012) <http://www.nrel.gov/docs/fy13osti/56776.pdf> accessed 22.10.2015, 3.

${ }^{195}$ RENERGY S.à r.l. v. Kingdom of Spain (ICSID Case No. ARB/14/18).

${ }^{196}$ Tirado 19.

${ }^{197}$ CSP Equity Investment S.à.r.l. v. Kingdom of Spain (Arbitration Institute of the SCC).

${ }^{198}$ Tirado 16.

${ }^{199}$ Masdar Solar \& Wind Cooperatief U.A. v. Kingdom of Spain (ICSID Case No. ARB/14/1).

${ }^{200}$ Tirado 18. 
With regard to the dispute settlement forum (Annex, Figure 5), one may note that the largest number of claims (69 percent) has been brought before the International Center for Settlement of Investment Disputes (ICSID). Other popular options are ad hoc arbitration in accordance with the UNCITRAL Arbitration Rules, ad hoc arbitrations administered by the Permanent Court of Arbitration (PCA); and claims brought before the Arbitration Institute of the Stockholm Chamber of Commerce (SCC).

Lastly, a notable peculiarity is the low variety among legal counsel (Annex, Figures 6 and 7) representing claimants in these cases. The largest number of claims are being represented on the claimant side of the dispute by the global law firms of Allen \& Overy and King \& Spalding; and national law firms, ArbLit - Radicati di Brozolo Sabatini and Cuatrecasas Gonçalves Pereira. These firms acting for claimants in PV solar investment cases may be further classified as 'acting internationally' (retained as counsel in PV solar disputes in several jurisdictions) and 'acting locally' (concentrating on one particular jurisdiction). The former include such firms as Allen \& Overy and King \& Spalding, while the latter include Herbert Smith Freehills (Spain) and Weil Gotshall \& Manges (the Czech Republic).

These claims are receiving increasing attention from affected states. A wide-quoted example $^{201}$ from the year 2011 mentions that the Czech Republic abandoned its policy of public tender proceedings for representation in international disputes and instead formed a 'dream team' of high-profile arbitrators for the sole purpose of combatting its PV solar claims. However, the increasing caseload has positive meaning as well: it has been suggested ${ }^{202}$ that some states might not revoke support schemes for fear of becoming subject to ITA claims. Such a positive 'chilling effect' might positively impact environmental policies that seek promoting RE.

Another consequence includes the increasing attention of law firms. PV solar disputes offer good revenue for investment lawyers, who can represent claimants in one or several juris-

\footnotetext{
201 David Elward, 'Czech Republic takes new approach as ECT claims loom' (Global Arbitration Review, 2011) <http://globalarbitrationreview.com/news/article/29583/czech-republic-takes-new-approach-ectclaims-loom/> accessed 12.11.2015.

202 Avidan Kent, 'Renewable Energy Disputes Before International Economic Tribunals: A Case for Institutional 'Greening'?' (2015) 12 Transnational Dispute Management, 9.
} 
dictions. A relevant example was recently noted in the Czech Republic, where a national law boutique promoted aggressive legal advertisement for PV solar investors. ${ }^{203}$ It can also happen to two abovementioned international law firms, which are currently dominating on the PV solar market.

To conclude, the analysis shows a growing body of cases, which have many similarities. Some similarities can be explained relatively easily (the limited choice of forum or legal instrument, which is typical for intra-EU disputes), and some will require additional research when more factual data becomes available. Another distinct issue is the choice and appointment of arbitrators, who also seem to lack diversity in PV solar investment cases and show repeated appointments; ${ }^{204}$ a thorough analysis of this issue will be possible once the procedure of tribunal constitution is finalized in current disputes.

\subsection{The relevant standards of investment treaties}

As stated in the previous section, the majority of RE investment claims are currently filed under the ECT, with only few claimants invoking intra-EU BITs. For this reason, one may presume that the number of relevant substantive guarantees invoked does not differ significantly between the disputes.

A previous study ${ }^{205}$ suggests that the number of guarantees which could be potentially infringed in PV solar cases based on the $\mathrm{ECT}^{206}$ include provisions on direct, indirect and partial expropriation, the FET standard and the umbrella clause. The study concluded that the FET standard is best suited due to the specific peculiarities of RE reduction schemes. ${ }^{207}$ While this speculation is reasonable, it is also necessary for the purposes of this study to

\footnotetext{
${ }^{203}$ Cecilia Olivet, 'A test for European solidarity: The case of intra-EU Bilateral Investment Treaties' (Transnational Institute, 2013) 7 <https://www.tni.org/files/download/briefing_on_intra-eu_bits_0.pdf> accessed 12.11.2015.

${ }^{204}$ Luke Eric Peterson and Zoe Williams, 'ICSID Renewables Claims Against Spain Reach 23, Along With Some Signs of Repeat Arbitrator Appointments - But No Common Chairs As Yet' (IAReporter, 2015) $<$ http://www.iareporter.com/articles/icsid-renewables-claims-against-spain-reach-23-along-with-some-signsof-repeat-arbitrator-appointments-but-no-common-chairs-as-yet/> accessed 18.11.2015.

${ }^{205}$ Reuter.

${ }^{206}$ Ibid 9-49.

${ }^{207}$ Ibid 49.
} 
briefly introduce the applicability of relevant standards, abstracting from exact treaty provisions. Confining one's analysis to the ECT forecloses the differences in protection standards that might be available under intra-EU BITs.

In this section, an analysis of the following standards of protection will be discussed: (i) the FET standard; (ii) prohibition against indirect expropriation; (iii) non-discrimination provisions; and the (iv) umbrella clause.

\subsubsection{The fair and equitable treatment (FET) standard}

The FET standard provides with the broadest coverage of activities in comparison to other standards and frequently forms the basis of investment treaty claims. ${ }^{208}$ Breach of the FET standard forms the majority of claims recognized in ITA to date. ${ }^{209}$ The PV solar claims emerge from a sudden change of state policies and are likely to follow this tradition.

The all-embracing nature of the FET standard poses questions with regard to its precise meaning and content. It has been stated that the standard is too case-specific and cannot be assessed in the abstract. ${ }^{210}$ Nevertheless, practical considerations call for certain classification. Tribunals tend to identify certain subgroups within the standard, but they lack a uniform approach. ${ }^{211}$

In arbitral tribunal jurisprudence, it has been suggested that the FET standard could be classified as embracing a number of partly overlapping criteria, which include: (i) good faith and consistency of conduct; (ii) transparency and purposefulness of legal rules; (iii) compliance with the due process; (iv) absence of arbitrary, discriminative or harassing behavior on behalf of the state; and inter alia (v) "a reasonable degree of stability and predictability of the legal system together with the recognition of the investors' legitimate expecta-

\footnotetext{
${ }^{208}$ Rudolf Dolzer, 'Fair and Equitable Treatment: Today's Contours' (2013) 12 Santa Clara J Int'l L 7, 10.

${ }^{209}$ Rudolf Dolzer and Christoph Schreuer, Principles of international investment law (Oxford University Press 2012) 130.

${ }^{210}$ Mondev International Ltd. v. United States of America [2002] (ICSID Case No. ARB(AF)/99/2 11.10.2002), § 118 .

${ }^{211}$ Dolzer 14-15.
} 
tions.",212

Empirical evidence provided in the previous suggests that the latter criterion is likely to be the most debated one. Indeed, in abruptly changing its support schemes, states may have undermined the trustworthiness of their legal systems, and caused disturbance in the flow of investment. The violations of legitimate expectations will be discussed in the next section.

\subsubsection{Indirect expropriation}

In case of indirect expropriation, the property title remains unchanged, but its enjoyment appears limited. ${ }^{213}$ According to an earlier study, the revocation of preferable FITs and change of support schemes can represent indirect expropriation. ${ }^{214}$ Indeed, in the majority of PV solar claims, states granted investors certain vested rights, which were later infringed by subsequent legislation. This discussion poses a two-fold question: whether these changes were performed within the scope of state regulatory authority and whether they shall be deemed compensable?

The state legal framework is never static and shall be adjusted to new challenges. Conditions created by earlier legislation can be narrowed down due to budgetary needs. For example, in the Oscar Chinn case the Permanent Court of International Justice (PCIJ) did not recognize protected vested right in "favorable business conditions," noting that they are "transient circumstances, subject to inevitable changes." 215 Therefore the reductions may not constitute indirect expropriation if they resulted from genuine regulatory action.

That brings us to the second part of the question, namely, the emerging doctrine of regulatory expropriation. Accordingly, arbitral tribunals ${ }^{216}$ seem to agree that measures which

212 Ibid 15. See also Jacob Stone, 'Arbitrariness, the fair and equitable treatment standard, and the international law of investment' (2012) 25 Leiden Journal of International Law 77-107, 83-85.

${ }^{213}$ Dolzer and Schreuer 101.

${ }^{214}$ Rachel A. Nathanson, 'The revocation of clean-energy investment economic-support systems as indirect expropriation post-nykomb: A spanish case analysis' (2013) 98 Iowa Law Review 863-904, 904.

${ }^{215}$ The Oscar Chinn Case [1934] (Permanent Court of International Justice 12.12.1934), 27.

${ }^{216}$ Azurix Corp. v. Argentine Republic [2006] Award (ICSID Case No. ARB/01/12 14.07.2006), §§ 310-312; LG\&E Energy Corp., LG\&E Capital Corp., and LG\&E International, Inc .v. Argentine Republic [2006] Decision on Liability (ICSID Case No. ARB/02/1 03.10.2006), § 195. 
were adopted on a non-discriminatory basis for the purposes of general regulation do not constitute expropriation and thus shall not be compensated. Empirical evidence shows that the reasons for the tariff reductions were budgetary needs, which are within a state's police powers. The question thus is in the manner of implementation (i.e. its proportionality, nondiscriminatory application and compliance with due process), which shall be assessed on a case-by-case basis.

Finally, a relatively recent development is that the notion of legitimate expectations has appeared in the discussion on indirect expropriation (i.e. it is not a notion confined to analysis under the FET standard). ${ }^{217}$ Given that this criterion originates in and partially overlaps with the FET standard, it is not necessary to elaborate further on the concept of legitimate expectations in regard to indirect expropriation due to the general preference of ITA tribunals ${ }^{218}$ for the competing and more flexible FET standard.

\subsubsection{Non-Discrimination}

Non-discrimination provisions are traditionally included as separate protections in investment treaties, and they can also form part of the FET standard. Under these provisions, states are obliged to treat foreign investors no less favorably than their own investors and investors from third states.

It has been suggested ${ }^{219}$ that the RE policies of EU Member States may constitute discriminatory treatment for two reasons. Firstly, because of the local content requirement included in some support schemes: the FIT schemes in France, Italy, Greece and Croatia grant additional bonuses to those producers who used equipment of EU origin. Second, because of a local consumption requirement: when the produced energy should be purchased by the local electricity distributor in order to receive FIT incentives. In support of these allegations, it is worth noting that the local content requirement of the Italian support scheme was re-

\footnotetext{
${ }^{217}$ Dolzer and Schreuer 115.

${ }^{218}$ Ibid 101.

${ }^{219}$ Behn and Fauchald 119.
} 
cently challenged $^{220}$ by China in the WTO dispute settlement body as a trade-distortive discriminatory measure. ${ }^{221}$

\subsubsection{Umbrella clause}

An umbrella clause guarantees the observance of state contractual and other commitments towards the investor, and brings them under investment treaty protection. ${ }^{222}$ This clause is often included in investment treaties, but began to receive attention fairly recently in the last 15 years. $^{223}$

The academic debate concerning the application of umbrella clause is centered on the form and scope of commitments. Initially, arbitral tribunals ${ }^{224}$ tended towards a broad interpretation covering all types of commitments. Indeed, a restrictive interpretation ${ }^{225}$ which excludes non-contractual obligations because of potential flood of lawsuits remains a highly criticized and isolated one. ${ }^{226}$ The current arbitral jurisprudential trend seems to recognize a distinction between acta jure imperii and acta jure gestionis, where the umbrella clause protection refers to the former. ${ }^{227}$ Indeed, the violation of an umbrella clause should involve some public authority beyond the 'simple' breach of contract, when the state "steps out of its role of an ordinary contracting party."228 Therefore the umbrella clause protection may be applicable not only to contractual arrangements, but also to obligations assumed by

${ }^{220}$ European Union and certain Member States - Certain Measures Affecting the Renewable Energy Generation Sector (Dispute Settlement of the World Trade Organization, DS452).

${ }^{221}$ Behn and Fauchald 126; Chien-Huei Wu \& Kuei-Chih Yang, 'Aggressive Legalism: China's Proactive Role in Renewable Energy Trade Disputes?’ (2015) 12 Transnational Dispute Management.

${ }^{222}$ Dolzer and Schreuer 166.

${ }^{223}$ Ibid 168-169.

${ }^{224}$ SGS Société Générale de Surveillance S.A. v. Republic of the Philippines [2004] Decision of the Tribunal on Objections to Jurisdiction (ICSID Case No. ARB/02/6 29.01.2004), § 128; Eureko B.V. v. Republic of Poland [2005] Partial Award (Tribunal ad hoc 19.08.2005), § 246.

${ }^{225}$ SGS Société Générale de Surveillance S.A. v. Islamic Republic of Pakistan [2003] Decision of the Tribunal on Objections to Jurisdiction (ICSID Case No. ARB/01/13 06.08.2003), § 168.

${ }^{226}$ Dolzer and Schreuer 172.

${ }^{227}$ Ibid 173.

${ }^{228}$ Ivar Alvik, Contracting with sovereignty: state contracts and international arbitration (Bloomsbury Publishing 2011) 188. 
states in unilateral way, through their legislation or executive acts. ${ }^{229}$

Support schemes for PV solar investments may fall under umbrella clause protection for both contractual and non-contractual arrangements. As we have seen, the Italian regulatory policy envisaged ${ }^{230}$ payment agreements between RE producers and the state-owned electricity distribution company. Failure of the state-owned enterprise to respect such contracts may elevate a breach of these arrangements to a violation of the applicable treaty. However, in most PV solar support schemes the specific promises were given to investors in host state legislation, not through contracts. They do not represent contractual arrangements, but unilateral obligations of states to accord certain preferable treatment. The treaty protection of such obligations has been previously characterized ${ }^{231}$ as falling under the umbrella clause standard.

\subsection{Promised pie in the sky: FET and RE investment claims}

As mentioned in the previous section, the legitimate expectations of the investor form the central part of the FET standard. If an investor relies on state promises, which influence her decision to invest or to proceed with investment, then that investor may have a legitimate expectation in the state fulfilling that promise. In the described scenarios relating to PV solar support schemes, the reduction of incentives was often performed contrary to initial promises, with retroactive or retrospective effect and without proper notifications to investors.

In regard to the reduction in PV solar support schemes, the legitimate expectations of investors may have been violated by the following measures: (i) the introduction of new restrictions to PV solar projects; (ii) retroactive and retrospective policy changes; (iii) lack of transparency in decision-making; (iv) failure to adopt remedial legislation; and (v) bad faith behavior of states.

\footnotetext{
${ }^{229}$ Dolzer and Schreuer 177-178.

${ }^{230}$ Massari 14.

${ }^{231}$ LG\&E v Argentine, $§ 174$.
} 


\subsubsection{New restrictions to PV solar projects}

In several cases described (Spanish Decree Law 15/2012, amendments to the Italian 'Robin Hood law ${ }^{232}$ ) states introduced taxation measures which were implicitly targeting RE and particularly PV solar investments. These types of measures have the possibility of violating two separate investment treaty standards as being contrary to an investor's legitimate expectations: protection against indirect expropriation without adequate compensation and the FET standard.

In both instances the severity of deprivations will be evaluated with a careful eye to the scope of the state's police powers. Previous tribunals have repeatedly argued that the execution of a regulatory right per se does not constitute a treaty violation. There are no cases, where compensation was ordered for legitimate environmental regulatory measures. ${ }^{233}$ In the Lemire II case, ${ }^{234}$ the Tribunal noted that the claim for material wrongfulness of the regulatory decision will not suffice for a breach, so long as the state organ did not act in an arbitrary or capricious way. ${ }^{235}$

What is an 'arbitrary action' and how its prohibition relates to the FET standard is still subject to academic debate and has no uniform answer in arbitral practice. ${ }^{236}$ The test adopted by the International Court of Justice (ICJ) in the ELSI case ${ }^{237}$ was supported in practice as a crucial threshold for the finding of arbitrary action. ${ }^{238}$ According to the Court, such action should constitute "a willful disregard of due process of law, an act which shocks, or at least surprises, a sense of juridical propriety."239 It seems doubtful whether this high threshold

\footnotetext{
${ }^{232}$ A series of Italian laws were amended so that RE producers faced significant taxes together with fossil energy producers. The law was recognized unconstitutional by the Italian Constitutional Court, see Sentenza 10 [2015] (La Corte Constituzionale 09.02.2015).

${ }^{233}$ Sadie Blanchard and Charles N Brower, "From" Dealing in Virtue" to" Profiting from Injustice": The Case Against" Re-Statification" of Investment Dispute Settlement' (2014) 55 Harvard International Law Journal, 54-58

${ }^{234}$ Joseph C. Lemire v. Ukraine [2011] Award (ICSID Case No. ARB/06/18 28.03.2011).

${ }^{235}$ Ibid, $\S 283$.

${ }^{236}$ For the comprehensive review see Stone.

${ }^{237}$ Elettronica Sicula S.p.A. (ELSI) (United States of America v. Italy) [1989] ICJ Reports 1989, 15 (International Court of Justice, Judgment 20.07.1989).

${ }^{238}$ Stone $96-97$.

${ }^{239}$ ELSI case, § 128.
} 
could be violated in the PV solar cases, where the adoption of restrictive measures was motivated by more or less genuine budget concerns, and therefore is less likely to appear 'shocking' or 'surprising.' After all, the Member States shall always be able "to control the effect and costs of their national support schemes according to their potential, whilst maintaining investor confidence," as noted by the CJEU in the recent Essen Belgium case. ${ }^{240}$ What is worth mentioning is that qualification of action as arbitrary may depend not only on the state's behavior, but also on investor's legitimate expectations. As it was noted by the Tribunal in the Alpha Projectholding case, ${ }^{241}$ the arbitrary change of the "rules of the game" which could undermine the legitimate expectations or representations made to the investor shall be avoided. ${ }^{242}$ As has been seen from the overview of RE policies in certain EU Member States, states initially induced investors by subjecting them to a preferable regulatory (especially, taxation) regime, which was perceived as a guarantee of stable and favorable treatment by investors. Therefore, even if new regulatory changes were adopted for a reasonable and valid public purpose, they may still run contrary to the investors' expectations and could amount to an arbitrary action.

Finally, new deprivatory measures specifically targeted PV solar investments, leaving untouched other RE investments (examples include Czech Law 402/2010 and Spanish Decree 1/2012). What can be seen from the overview of RE policies is that some of these measures discriminated between different types of investors, without any reference to their nationality (and thus beyond the traditional debate of national and most favorable nation treatment obligations). Can such measures be considered discriminatory? A three-fold test has been developed in ITA jurisprudence ${ }^{243}$ for the identification of discriminatory measures: (i) identification of a 'like situation' or 'like circumstances;' (ii) presence of less favorable treatment; and (iii) absence of any justification for discriminatory treatment. The second criterion, less preferable treatment of PV solar investors in comparison to other RE inves-

\footnotetext{
240 Joined cases C-204/12 to C-208/12 Essent Belgium NV v Vlaamse Reguleringsinstantie voor de Elektriciteits- en Gasmarkt [2014] (ECJ 11.09.2014), § 102.

${ }^{241}$ Alpha Projektholding GmbH v. Ukraine [2010] Award (ICSID Case No. ARB/07/16 08.11.2010).

${ }^{242}$ Ibid, $\S 420$.

${ }^{243}$ Dolzer and Schreuer 199.
} 
tors was described in an earlier section. ${ }^{244}$ Therefore, this section will only consider the remaining two issues: whether PV solar energy producers and producers of other types of RE were in 'like' circumstances; and whether the discriminatory character of deprivatory measures can be justified by legitimate reasons?

With regard to the first criterion, one may see that investment in PV solar projects benefitted significantly from the introduction of cheap PV solar panel technologies, which did not happen to other RE producers. Therefore, PV solar investors eventually appeared in more favorable conditions than other investors and these conditions cannot be characterized as 'like." The second criterion logically follows: the increase in the PV solar market required states to implement mitigation measures tailored specifically to this type of investment. It may be concluded that the discrimination between investors in different types of RE was legitimized by the distinctively different position of PV solar investors.

\subsubsection{Retroactive and retrospective application of reductions}

As seen in the overview of RE policies in certain EU Member States, there was a certain point where the initial over-incentivization of PV solar investment became unbearable for state budgets. The inducement of prospective investments was prevented by the introduction of capacity caps and gradual tariff reductions. However, the central question remains with regard to admitted investments, which were guaranteed stable tariff rates for 15 to 25 years. Implementation of retroactive and retrospective measures became the common way for states to reduce expenses. It follows that such negative changes can form the basis of an FET claim.

As a preliminary point, it is important to avoid terminological confusion. The legal doctrine distinguishes between 'retroactive' and 'retrospective' measures. The distinction is debated, and according to one highly persuasive source ${ }^{245}$ the terms can be used interchangeably. However, both terms can help in the categorization of different measures, and therefore are worth introducing. The simple distinction can be framed as follows: a retrospective statute

\footnotetext{
${ }^{244}$ See the case study in Section 3.

${ }^{245}$ Black's Law Dictionary (9 edn, Thomson Reuters 2009) 1432.
} 
has prospective character, but arises from past events, while a retroactive statute changes the initial law and thus applies to past, present and future events. ${ }^{246}$ An earlier study ${ }^{247}$ on retroactive and retrospective reductions of PV solar support schemes concluded that in the majority they have 'retrospective' rather than 'retroactive' force. ${ }^{248}$ This argument has limited value in abstracto: according to these authors, ${ }^{249}$ the legality of both types of measures is highly dependent on the applicable law as different standards have been elaborated in national legal systems and under EU law.

Turning back to investment arbitration, one may suggest that retroactive changes may be permissible under a state's police powers and thus fall outside the scope of investment treaty protection. However, these reductions have one significant difference from general regulatory measures: specification. States expressly guaranteed stable tariff rates, and failure to respect them is likely to constitute a violation of FET. A similar line of argumentation is applicable to the indirect expropriation standard, where the frustration of investors shall originate from the revocation of state's specific commitments. ${ }^{250}$

The stress on specificity is supported by arbitral tribunal practice. In $E D F,{ }^{251}$ the Tribunal drew a line between changes relating to a "State's normal regulatory power and the evolutionary character of economic life," which do not constitute a breach of the FET, and changes in violation of specific promises and representations, which can violate this standard. ${ }^{252}$ However, the form of expression may matter: in the PV solar cases the guarantees were expressed in host state legislation and not investment contracts.

A regulatory right is characterized as a reserved right, which can be exercised by the state in the absence of specific and concrete stabilization arrangements. ${ }^{253}$ An earlier study ${ }^{254}$ suggested that, in the absence of stabilization contract clauses, states could plan stabiliza-

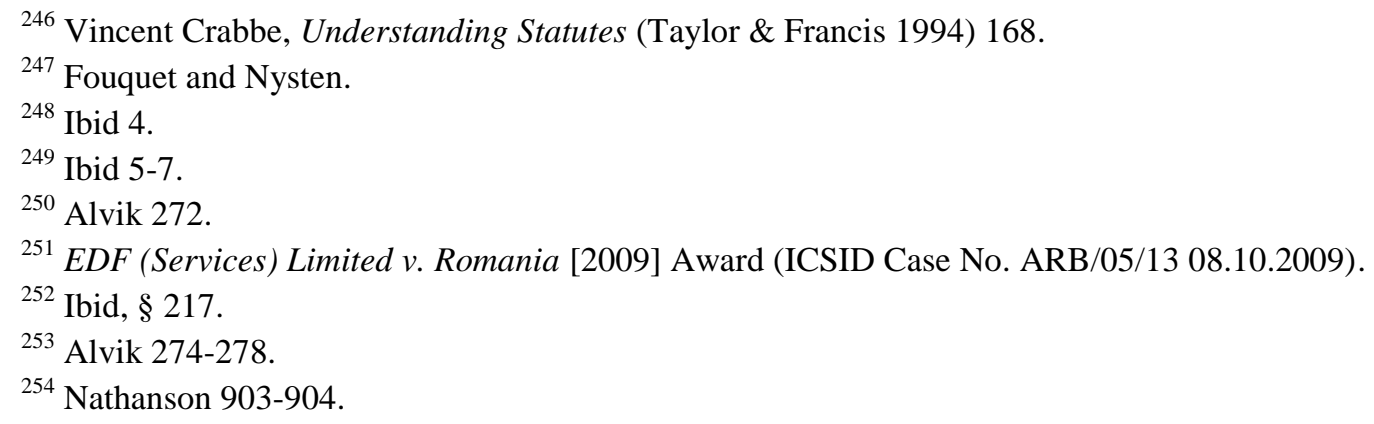


tion mechanisms in advance during treaty negotiations. These authors recommend states to fasten their commitments towards RE objectives by expressly promising to treat any revocation of benefits for RE projects as a compensatory expropriation. This proposal can hardly be recognized as viable. Enlarging the scope of stabilization clauses to the uncountable quantity of investors could significantly narrow down the state's regulatory freedom. One can only imagine what would have happened if all PV solar investments were structured through contracts with stabilization clauses, depriving states from genuine regulatory right for changing circumstances and leading to massive unconditioned compensations.

In conclusion, it may be reiterated that in order to avoid FET-related claims states need to be careful with regard to both the form and scope of their commitments in support schemes. The unavoidable deprivatory measures must be strictly within the corridor of permissible regulatory action in compliance with given guarantees and representations.

\subsubsection{Lack of transparency in decision making process}

Even an unfavorable decision may be legitimized by broad discussion with investors and a state's continuous efforts to achieve public consensus. Failure to disclose regulatory plans and to discuss future negative amendments would therefore lead to misunderstanding between the state and investors, and push the latter to different mechanisms of protection, including ITA.

As indicated earlier, transparency in the regulatory decision-making process forms one of the constitutive elements of the FET standard. ${ }^{255}$ In the Metalclad case, ${ }^{256}$ the Tribunal declared that there should be "no room for doubt or uncertainty" in the legal framework surrounding the investment. ${ }^{257}$ The Tribunal concluded that Mexico failed to ensure "a transparent and predictable framework" for the investment. ${ }^{258}$ In the Maffezini case, ${ }^{259}$ the Tri-

\footnotetext{
${ }^{255}$ Dolzer and Schreuer 149-152.

${ }^{256}$ Metalclad Corporation v. The United Mexican States [2000] Award (ICSID Case No. ARB(AF)/97/1 30.08.2000).

${ }^{257}$ Ibid, $§ 76$.

${ }^{258}$ Ibid, $§ 99$.

${ }^{259}$ Emilio Agustín Maffezini v. The Kingdom of Spain [2000] Award (ICSID Case No. ARB/97/7 13.11.2000)
} 
bunal declared that the lack of transparency in the transaction was incompatible with the FET obligation. ${ }^{260}$

Our analysis shows that governments have used different forms of investor participation in the decision-making process related to PV solar incentives. From the year of 2000, the Czech ERO was obliged to publish electricity tariffs for public discussion. In Germany any new reduction in tariff rates permitted under the Renewable Energy Sources Act must also be preceded by a public discussion, where suggestions from investors are accumulated and distributed on a special website. The tariff cuts in Spain were reportedly ${ }^{261}$ preceded by consultations with energy firms (however, a more recent report mentioned that the RE industry "seems to be entirely ignored" during policy negotiations ${ }^{262}$ ). As a generally accepted policy, states often involve stakeholders in public discussion as a means of preventing rumors, uncertainty and frustration from investors.

Transparency has paramount importance for the financial stability of investors. For example, in small-scale PV solar investments (often installed by families within a single household), many investment were made with borrowed money on the assumption of astable return. The recent Spanish critique ${ }^{263}$ of incentive cuts referred to a significant sum of money which local households had invested in PV solar projects, and later faced as a banking debt without possibilities of repayment. Similar problems were observed in the Italian market. ${ }^{264}$ In Spain this situation eventually resulted in mass protest demonstration against the cuts. It may be concluded, that timely consultations and broad media coverage of decision-making processes could help to safeguard the financial standing of investors and protect their legitimate expectations.

Lastly, it is worth mentioning that investors should be attentive to the ongoing discussions

${ }^{260}$ Ibid, $\S 83$.

261 James Murray, 'Spain proposes deep cuts to solar PV support' (The Guardian, 2010) <http://www.theguardian.com/environment/2010/aug/03/spain-cuts-solar-pv> accessed 07.11.2015.

${ }^{262}$ Fouquet and Nysten 26.

263 'El gobierno español aprueba los nuevos recortes al sector renovable' (PV Magazine Latinoamérica, 2014) <http://www.pv-magazine-latam.com/noticias/detalles/articulo/el-gobierno-espaol-aprueba-los-nuevosrecortes-al-sector-renovable_100015591/> accessed 24.10.2015.

${ }^{264}$ Massari 9, footnote 18. 
and to constantly monitor the legal framework of the host state. In the Plantanol case, ${ }^{265}$ the CJEU declared that a "prudent and circumspect economic operator" cannot plead the principle of protection of legitimate expectations if they could have foreseen the adoption of unfavorable measure. Such measures are often preceded by broad public discussion and media coverage, which makes pleading of reasonableness of expectations even more difficult. $^{266}$

\subsubsection{Failure to adopt mitigating measures}

Even facing the need of regulatory action, the state may respect investors' expectations by substituting the costly support schemes with a mitigating regulation. This helps to prevent an "all or nothing" deadlock, when the maintenance of measures in the full amount is no longer possible. Investors thus may either agree to the proposed changes, or object to them, facing an unpredictable conflict over the scope of state police powers.

A relevant example can be found in the series of Italian reforms. As noted earlier, the emergency legislative intervention of $2014^{267}$ placed three options ${ }^{268}$ before investors. All three options required a change to the guaranteed incentive scheme, but gave investors options as to which reduction is best suited for their particular circumstances. Investors were asked to communicate their preferred choice before 30 November 2014. In the absence of such communication, one of three options applied to them by default. In addition, the decree suggested $^{269}$ mitigating the hurdles of investors by loans with favorable conditions provided by the Deposit Fund (Cassa Depositi e Prestiti S.p.A.). The law further prescribed for the Ministry of Economics and Finance to adopt regulation for these loans. A recent critique $^{270}$ emphasized that these loans were not adopted within the expected time limits. Ten days before the deadline for communication, the Italian Association of Renewable En-

\footnotetext{
${ }^{265}$ Case C-201/08 Plantanol GmbH \& Co. KG v Hauptzollamt Darmstadt [2009] (ECJ 10.09.2009), § 53.

${ }^{266}$ Fouquet and Nysten 7.

${ }^{267}$ Law 91/2014.

${ }^{268}$ Ibid, Article 26(3).

${ }^{269}$ Ibid, Article 26(5).

${ }^{270}$ Massari 8; Fouquet and Nysten 19.
} 
ergy Producers (AssoRinnovabili) urged ${ }^{271}$ the awareness of investors' instability and called for the postponement of the deadline. Only in January 2015 the Ministry published the decree $^{272}$ clarifying the situation with loans. This measure included state guarantees in the amount up to the 80 percent of the producers' debt before the credit institutions, payable in case of producers' default.

What can be evidenced in this example is that from one side the state pressured investors' towards depriving measures by promising them effective mitigation. From another side, the state failed to adopt these mitigating measures in a timely manner. As a result, during the fall of 2014 investors in Italy faced a great amount of uncertainty and unpredictability with regard to future policy changes. The lack of the state's timely reaction thus undermined their legitimate expectations.

\subsubsection{Bad faith behavior}

Previous tribunals have underlined the importance of good faith behavior when assessing the FET standard. In the Waste Management case, the Tribunal characterized ${ }^{273}$ acting in good faith as a basic requirement under the FET standard. Later, in the Sempra case, the Tribunal placed good faith at the heart of FET standard. ${ }^{274}$

One may find evidence of bad faith behavior in public statements of state officials concerning PV solar investors. For example, the prime minister of Czech Republic has reportedly expressed some verbal attacks on PV solar investors, characterized as 'solar barons. ${ }^{, 275}$ The general 'bad media' reaction over PV solar projects is observed in most EU Members States and its improvement is recognized as one of the primary goals of RE policy re-

271 'Spalma-incentivi, assoRinnovabili: "ritardo decreti impedisce scelta, si proroghi il termine"' (Qualenergia.It, 2014) <http://www.qualenergia.it/articoli/20141114-spalma-incentivi-assorinnovabili-algoverno-urge-decreto-su-accesso-ai-finanziamenti-bancari> accessed 04.11.2015.

${ }^{272}$ Decreto Ministeriale [Decree on Loans for Incentive Holders], 29.12.2014, GU No. 17 del 22.01.2015.

${ }^{273}$ Waste Management, Inc. v. United Mexican States ("Number 2") [2004] (ICSID Case No. ARB(AF)/00/3 30.04.2004), § 138.

${ }^{274}$ Sempra Energy International v. The Argentine Republic [2012] (ICSID Case No. ARB/02/16 28.09.2007), $\S 298$.

275 Martin Sedlák, 'Cloudy skies over Czech photovoltaics' (The Energiewende Blog, 2014) $<$ http://energytransition.de/2014/10/cloudy-skies-over-czech-photovoltaics/> accessed 14.11.2015. 
forms. $^{276}$

Due to the vague and comprehensive character of bad faith behavior, it is impossible to make a definitive conclusion here. However, it may be deduced that the gross disregard of investors' positions, which was exercised in an arbitral and inconsistent manner, is likely to be recognized as a violation of the good faith requirement on behalf of the state. To the contrary, the more justifications states present for the change of support schemes and the more mitigating measures they adopt to save the investments, the less likely their conduct would be qualified as being in bad faith.

\subsection{States in Different Leagues: What Influences the Caseload?}

As we have observed earlier, European states face a different numbers of cases. On the basis of our analysis, it is suggested that following the groups of factors, alone or in combination, can generate this divergence in numbers: (i) factors relating to national RE policies; (ii) factors relating to arbitral process; and (iii) factors relating to investor behavior.

The first group of factors comprises inter alia different incentivization rates and responsiveness of the national legal framework to changing circumstances. It may be recalled that even the German support schemes were originally quite generous. However, the legislators in Germany managed to predict adverse consequences and quickly implement a number of measures (like capacity caps and gradual reductions) that balanced investors' expectations with state budget capabilities. In the German example, this success of support schemes was also achieved by the early research and development of appropriate RE policies, and strict compliance with EU rules on permissible state aid. Among other influential factors connected with RE policies, one needs to mention the geographical allocation of incentive schemes between different regions, depending on their investment attractiveness, and cooperation arrangements with neighboring states (e.g. electricity pool spot exchange models).

The second group of factors includes pre-dispute settlements, which remain unknown to general public, as well as domestic litigation attempts, which can appear time-consuming

\footnotetext{
${ }^{276}$ Fouquet and Nysten 25-26.
} 
and result in delays before filing an international claim. Another temporary factor, which does not lessen the number of claims, but postpones their initiation, is the treaty imposed cooling-off period of 3 to 6 months, prescribed by the ECT and infra-EU BITs. In order to prepare a well-substantiated international claim, investors may reasonably spend time in negotiations with governmental bodies and rely first on domestic courts, before elevating the case to the international level.

The third group includes proactive behavior of investors and their legal counsel. Investment arbitration is risky and expensive, and therefore requires good financial standing from investors. Minor investors either appear deprived of this means of dispute settlement, or first have to collect substantial sums to initiate the proceedings. Moreover, as has been seen in earlier sections, several law firms started specializing in arbitration of PV solar cases and are now amassing a significant number of clients, while firms with less experience may appear less decisive to initiate arbitral proceedings.

These three factors are not conclusive, and one may suggest using it only as a basic assumption of the underlying reasons for the variable caseload. More accurate categories will be achieved with a quantitative analysis of the cases once more information about them becomes publicly available.

\section{Chapter conclusions: Fear the avalanche}

As observed, PV solar investment cases arise from changes in legislation, which were specifically adopted for the large-scale inducement of investors. Common peculiarities of these cases include the following: (i) similarity in case patterns within one jurisdiction (identical causal factors; legal instruments invoked; legal teams acting); (ii) relatively low amount of damages requested in individual cases, while the total amount of claims tends to expand due to an increasing number of claimants; (iii) temporal factor - nearly simultaneous emergence of cases in several jurisdictions; and (iv) lack of knowledge - to the present date, cases are still pending, and the level of convergence in tribunal's reasoning seems rather questionable.

The influx of RE investment cases is likely to invoke several standards of investment protection. Although the exact combination appears rather imprecise due to the shortage of factual data, it is likely that four treaty standards could be invoked in the majority of PV 
solar cases: FET, indirect expropriation, non-discrimination and umbrella clause protection. Bearing in mind that the cases originated from a common factual background (revocation of state guarantees of stable treatment and incentive support), one may assume that broadest standard of FET is likely to be invoked in the absolute majority of cases. It has been long anticipated ${ }^{277}$ that legitimate expectations will play crucial role in the PV solar cases. In the analysis provided in this section, a number of popular policy measures of substantive and procedural nature have been identified, which were implemented by three most affected states - Spain, Italy and the Czech Republic, and which are all likely to affect investors' expectations. With regard to new restrictions and the retroactive and/or retrospective application of deprivatory measures, it may be concluded that the viability of these measures will depend on the tribunals' perception of state budgetary concerns as part of sovereign police powers, and their relation to the specific of commitments given to investors.

Speaking about procedural irregularities, it is suggested that a lack of transparency in decision-making process and a states' failure to adopt remedial legislation can undermine investors' expectations. Furthermore, the manifest disregard of investors' interests and negative media comments by state officials can evidence bad faith behavior on behalf of states, which may also signal a violation of the FET standard. The high value of the standard and the assessment of investors' expectations in the PV solar cases underline the importance of careful design of RE support schemes. States need to be cautious about the promises they give to investors and how they modify these promises afterwards.

${ }^{277}$ Luke Eric Peterson, 'Solar Investors File Arbitration Against Czech Republic; Intra-EU Bits and Energy Charter Treaty at Center of Dispute' (IAReporter, 2013) <http://www.iareporter.com/articles/solar-investorsfile-arbitration-against-czech-republic-intra-eu-bits-and-energy-charter-treaty-at-center-of-dispute/ $>$ accessed 14.11.2015. 


\section{Conclusions}

In this final section, it is useful to reiterate that PV solar investment disputes represent a novel area - for the EU and its Member States, as well as private investors and arbitration tribunals, which gain increasing popularity in the absence of established patterns of regulation and settlement of disputes at the domestic level. Many of the conclusions drawn in this thesis will require adjustments when more information about arbitral proceedings becomes available. Nevertheless, for the purposes of this study, the following can be concluded.

With regard to the influence of EU policies on RE investment disputes, the regulation of RE support schemes within the EU produced a gap between supranationally imposed objectives of RE promotion and individual responsibility of Member States under investment treaties. The EU has limited means of influence on investment arbitral proceedings, which are currently exercised through amicus curiae participation, and subsequent involvement into enforcement procedures. From a legal perspective, the main arguments of the EU involve both jurisdictional objections (termination or invalidity of intra-EU BITs) and substantive incompliance with EU law (primarily, regulations on permissible state aid). It is nevertheless doubtful whether tribunals will take any broader considerations of EU investment and environmental policies into account.

The overview of support measures for PV solar projects in selected EU Member States shows similar patterns: states adopted incentives in response to EU Directives, they experimented with tariff rates and eligibility criteria and, once confronted with budgetary needs, initiated reduction measures. However, the support schemes for PV solar investments show little convergence from the perspectives of ITA. Facing a technological change on the PV solar market, some states anticipated adverse changes and immediately adjusted their legislation, while other states took a longer time to respond. The policy fluctuations ultimately resulted in reduced or abandoned state support for PV solar investments, and an avalanche of RE investment claims.

PV solar investment cases have a number of common features. They all originate from deprivatory changes in legislation, which were specifically adopted for the large-scale inducement of investment in PV solar projects. They have similar case patterns within one jurisdiction (identical causal factors; legal instruments invoked; legal teams acting), and show a 
certain degree of similarity between different jurisdictions. Another common feature is the lack of knowledge, as all of cases are currently reported as pending. Therefore, the level of convergence among tribunals in their reasoning is largely an unknown variable presently. PV solar cases can be characterized as giving low protection for investors through domestic judicial or administrative remedies. States tend to downplay legitimate expectations of investors, secured by legislative guarantees, for the higher goal of regulatory freedom and sovereign right of adaptation to changing environment. This view is usually supported by national judiciaries. It this situation, investment arbitration provides a reasonable remedy for recovering frustrated investments. Nevertheless, the growing number of claims and alleged inconsistency of intra-EU BITs with the EU legal order may lead to strong political pressure against investment arbitration within the EU. The political deadlock between public society goals and individual investment protection will be first solved by arbitrators, who need to find a proper balance if they want to preserve investment arbitration within the EU.

Finally, as has been seen from the PV solar policy overview, there is a clash between national legal systems (where the judiciary favors legislative flexibility over stability of guarantees and representations); and investment jurisprudence where the focus is shifted towards investor's legitimate expectations. This conflict undermines the legitimacy of ITA, due to the following reasons. First, domestic and foreign investors receive different remedial rights. Domestic investors appear locked in their national legal systems, which deny any wrongdoing, while international investors can pursue treaty arbitration claims against host states. As a result, national investors are incentivized to perform investment structuring, thus depriving investment treaty protection of its primary goal: development of foreign investment flows. ${ }^{278}$ It is worth mentioning that the recent decision in the Occidental case $^{279}$ an ICSID Ad Hoc Committee warned against the expansion of personal jurisdiction

\footnotetext{
${ }^{278}$ M Sornarajah, 'Good Faith, Corporate Nationality, and Denial of Benefits' in Andrew D Mitchell, M Sornarajah and Tania Voon (eds), Good Faith and International Economic Law (Oxford University Press 2015) 134-135.

279 Occidental Petroleum Corporation and Occidental Exploration and Production Company v. Republic of Ecuador [2015] Decision on annulment (ICSID Case No. ARB/06/11 02.11.2015), §§ 262-264, 272.
} 
towards unprotected third parties. This decision can be interpreted as prohibiting abuse of ITA through mechanisms of 'treaty shopping, ${ }^{280}$ which may be used by national PV solar investors to gain treaty protection. Second, the divergent interpretation of the same factual circumstances (e.g. the legality of retrospective measures) by national courts and investment tribunals undermines the normative legitimacy of the latter. The recent extensive study $^{281}$ shows that arbitrators are generally reluctant to exercise restraint in adjudicating matters of national policy, pretending to be an "autonomous regime for categorical review" of states' actions. The proactive role of investment arbitration tribunals and their lack of deference to national decision-makers can therefore result in denial of their legitimate authority, and lead to a breakaway from the investment treaty regime.

To conclude, the gap between interpretations in the PV solar cases poses significant risks for the investment treaty regime and the development of investment arbitration. Both states and tribunals need to be careful and cooperative if they want to preserve positive perceptions of investment arbitration.

${ }^{280}$ Diane A. Desierto, 'Beneficial Ownership and International Claims for Economic Damage: Occidental Petroleum v. Ecuador and Restoring Limits to Investor-State Arbitral Tribunals' Jurisdiction Ratione Personae' (EJIL: Talk!, 2015) <http://www.ejiltalk.org/beneficial-ownership-and-international-claims-foreconomic-damage-restoring-limits-to-investor-state-arbitral-tribunals-jurisdiction-in-occidental-petroleum-vecuador/> accessed 16.11.2015.

${ }^{281}$ Gus Van Harten, Sovereign Choices and Sovereign Constraints: Judicial Restraint in Investment Treaty Arbitration (Oxford University Press 2013) 158 et seq. 


\section{Bibliography}

\subsection{Decisions of international courts and tribunals}

Achmea B.V. v. The Slovak Republic (formerly Eureko B.V. v. The Slovak Republic) [2010] Award on Jurisdiction, Arbitrability and Suspension (PCA Case No. 2008-13 26.10.2010)

Alpha Projektholding GmbH v. Ukraine [2010] Award (ICSID Case No. ARB/07/16 08.11.2010)

Azurix Corp. v. Argentine Republic [2006] Award (ICSID Case No. ARB/01/12 14.07.2006)

CSP Equity Investment S.à.r.l. v. Kingdom of Spain (Arbitration Institute of the SCC)

Eastern Sugar B.V.(Netherlands) v. The Czech Republic [2007] Partial Award (SCC Case No. 088/2004 27.03.2007)

EDF (Services) Limited v. Romania [2009] Award (ICSID Case No. ARB/05/13 08.10.2009)

EDF International S.A. v. Republic of Hungary [2014] (Tribunal ad hoc 04.12.2014)

Elettronica Sicula S.p.A. (ELSI) (United States of America v. Italy) [1989] ICJ Reports 1989, 15 (International Court of Justice, Judgment 20.07.1989)

Emilio Agustín Maffezini v. The Kingdom of Spain [2000] Award (ICSID Case No. ARB/97/7 13.11.2000)

Essent Belgium NV v Vlaamse Reguleringsinstantie voor de Elektriciteits- en Gasmarkt [2014] Joined cases C-204/12 to C-208/12 (ECJ 11.09.2014)

Eureko B.V. v. Republic of Poland [2005] Partial Award (Tribunal ad hoc 19.08.2005)

European Union and certain Member States - Certain Measures Affecting the Renewable Energy Generation Sector (Dispute Settlement of the World Trade Organization, DS452) 
Ioan Micula, Viorel Micula, S.C. European Food S.A, S.C. Starmill S.R.L. and S.C. Multipack S.R.L. v. Romania [2013] Final Award (ICSID Case No. ARB/05/20 11.12.2013)

Joseph C. Lemire v. Ukraine [2011] Award (ICSID Case No. ARB/06/18 28.03.2011)

LG\&E Energy Corp., LG\&E Capital Corp., and LG\&E International, Inc .v. Argentine Republic [2006] Decision on Liability (ICSID Case No. ARB/02/1 03.10.2006)

Masdar Solar \& Wind Cooperatief U.A. v. Kingdom of Spain (ICSID Case No. ARB/14/1)

Metalclad Corporation v. The United Mexican States [2000] Award (ICSID Case No. ARB(AF)/97/1 30.08.2000)

Mondev International Ltd. v. United States of America [2002] (ICSID Case No. ARB(AF)/99/2 11.10.2002)

Occidental Petroleum Corporation and Occidental Exploration and Production Company v. Republic of Ecuador [2015] Decision on annulment (ICSID Case No. ARB/06/11 02.11.2015)

The Oscar Chinn Case [1934] (Permanent Court of International Justice 12.12.1934)

Plantanol GmbH \& Co. KG v Hauptzollamt Darmstadt [2009] Case C-201/08 (ECJ 10.09.2009)

PreussenElektra AG $v$ Schhleswag AG [2001] Case C-379/98 (ECJ 13.03.2001)

RENERGY S.à r.l. v. Kingdom of Spain (ICSID Case No. ARB/14/18)

Sempra Energy International v. The Argentine Republic [2012] (ICSID Case No. ARB/02/16 28.09.2007)

SGS Société Générale de Surveillance S.A. v. Islamic Republic of Pakistan [2003] Decision of the Tribunal on Objections to Jurisdiction (ICSID Case No. ARB/01/13 06.08.2003) 
SGS Société Générale de Surveillance S.A. v. Republic of the Philippines [2004] Decision of the Tribunal on Objections to Jurisdiction (ICSID Case No. $\mathrm{ARB} / 02 / 6$ 29.01.2004)

Waste Management, Inc. v. United Mexican States ("Number 2") [2004] (ICSID Case No. ARB(AF)/00/3 30.04.2004)

\subsection{Domestic court practice}

Arrêt 4A_34/2015 du 6 octobre 2015, Cour de droit civil [2015] (Tribunal Fédéral Suisse 06.10.2015)

Beschluss $1 \mathrm{BvQ}$ 28/10 [2010] (Bundesverfassungsgericht 23.09.2010)

Photovoltaic Power Plants [2012] Judgment (Czech Republic Constitutional Court Case No. PI. ÚS 17/11 15.05.2012)

Sentencia 183/2014 [2014] BOE-A-2014-12649 293 (Tribunal Constitucional 06.11.2014)

Sentenza 10 [2015] (La Corte Constituzionale 09.02.2015)

Sentenza 119 [2010] (La Corte Costituzionale 22.03.2010)

\subsection{International treaties}

Consolidated version of the Treaty on the Functioning of the European Union [2012]

Kyoto Protocol to the United Nations Framework Convention on Climate Change [1997]

Treaty of Lisbon amending the Treaty on European Union and the Treaty establishing the European Community [2007]

United Nations Framework Convention on Climate Change [1992]

Vienna Convention on the Law of Treaties [1969]

\subsection{EU documents and materials}

'Commission asks Member States to terminate their intra-EU bilateral investment treaties' (European Commission, 2015) <http://europa.eu/rapid/pressrelease IP-15-5198 en.htm> accessed 11.11.2015 
European Council Presidency Conclusions 8-9.03.2007 $<$ http://www.consilium.europa.eu/uedocs/cms data/docs/pressdata/en/ec/93135.p df $>$ accessed 30.09.2015

Commission Decision (EU) 2015/1470 [2015] OJ L 232

Communication from the Commission Ref. Ares(2014)1576095 - 16/05/2014 Amicus Curiae Brief In PCA case No. 2013-6 (Arbitration under the 1976 UNCITRAL Arbitration Rules) U.S. Steel Global Holdings I B.V. (The Netherlands) [2014]

Communication from the Commission Guidelines on State aid for environmental protection and energy 2014-2020 [2014] OJ C 200

Communication from the Commission on State aid SA.38517(2014/C) (ex 2014/NN) - Romania [2014] OJ L 232

Communication from the Commission COM/2014/015 A policy framework for climate and energy in the period from 2020 to 2030 [2014]

Communication from the Commission State aid SA.31236 (2011/N) - Ireland [2011] JOCE C/312/2012

Communication from the Commission State aid SA.35177 (2014/NN) - Czech Republic [2014] JOCE C/280/2014

Community guidelines on State aid for environmental protection [2008] OJ C $82,1.4 .2008$

Directive (EC) 2001/77/EC of 27 September 2001 on the promotion of electricity produced from renewable energy sources in the internal electricity market [2001] OJ L 283/33

Directive (EC) 2009/28/EC of the European Parliament and of the Council of 23 April 2009 on the promotion of the use of energy from renewable sources and amending and subsequently repealing Directives 2001/77/EC and 2003/30/EC [2009] OJ L 140/16

\subsection{Domestic legislation}

Decreto-legge No. 91, 24.06.2014, GU No. 144 del 24.06.2014

Decreto legislativo No. 387, 29.12.2003, GU No. 25 del 31.01.2004 
Decreto Ministeriale, 06.02.2006, GU No. 38 del 15.02.2006

Decreto Ministeriale [Decree on Loans for Incentive Holders], 29.12.2014, GU No. 17 del 22.01.2015

Decreto Ministeriale [Primo Conto Energia], 28.07.2005, GU No. 181 del 05.08.2005

Decreto Ministeriale [Quarto Conto Energia], 05.05.2011, GU No. 109 del 12.05.2011

Decreto Ministeriale [Quinto Conto Energia], 05.07.2012, GU No. 159 del 10.07.2012

Decreto Ministeriale [Secondo Conto Energia], 19.02.2007, GU No. 45 del 23.02.2007

Decreto Ministeriale [Terzo Conto Energia], 06.08.2010, GU No. 197 del 24.08.2010

Erneuerbare-Energien-Gesetz 2012 (EEG 2012) [Renewable Energy Sources Act 2012], 28.07.2011, BGBI. I S. 1634

Erneuerbares Energien Gesetz 2004 (EEG 2004) [Renewable Energy Sources Act 2004], 21.07.2004, BGBI. I S. 1918

Erneuerbares Energien Gesetz 2009 (EEG 2009) [Renewable Energy Sources Act 2009], 25.10.2008, BGBI. I S. 2074

Erstes Gesetz zur Änderung des Erneuerbare-Energien-Gesetzes [First law amending the Renewable Energy Sources Act 2009], 11.08.2010, BGBI. I S. 1170

Gesetz für den Ausbau erneuerbarer Energien (Erneuerbare-EnergienGesetz - EEG 2014) [Act on the Development of Renewable Energy Sources, Renewable Energy Sources Act - RES Act 2014], 21.07.2014, BGBI. I S. 1066

Gesetz für den Vorrang Erneuerbarer Energien [Renewable Energy Sources Act 2000], 29.03.2000, BGBI I S. 305

Gesetz über die Einspeisung von Strom aus erneuerbaren Energien in das öffentliche Netz [Law on feeding electricity from renewable energy sources into the public grid], 07.12.1990, BGBI. 1990 I S. 2633 
Gesetz zur Neuregelung des Energiewirtschaftsrechts [New law for the energy industry], 24.04.1998, BGBI. 1998 I S. 730

Gesetz zur Änderung des Rechtsrahmens für Strom aus solarer Strahlungsenergie und zu weiteren Änderungen im Recht der erneuerbaren Energien [Law amending the legal framework for Electricity from solar radiation energy and further amendments in the Renewable Energy Sources Act, "PV novelle'], 17.08.2012, BGBI. I S. 1754

Legge della Regione Puglia No. 31, 21.10.2008

Legge No. 9, 09.01.1991, GU No. 13 del 16.01.1991

Legge No. 116, GU No. 192 del 20.08.2014

Ley 15/2012, 27.12.2012, BOE-A-2012-15649

Ley 24/2013, 26.12.2013, BOE-A-2013-13645

Ley 54/1997, 27.11.2997, BOE-A-1997-25340

Provvedimento No. 6, 29.04.1992, GU n. 109 del 12.05.1992

Real Decreto-ley 1/2012, 27.01.2012, BOE-A-2012-1310

Real Decreto-ley 2/2013, 01.02.2013, BOE-A-2013-1117

Real Decreto-ley 14/2010, 23.12.2010, BOE-A-2010-19757

Real Decreto 413/2014, 06.06.2014, BOE-A-2014-6123

Real Decreto 436/2004 [Decree 436/2004], 12.03.2004, BOE-A-2004-5562

Real Decreto 661/2007 [Decree 661/2007], 25.05.2007, BOE-A-2007-10556

Real Decreto 1565/2010, 19.11.2010, BOE-A-2010-17976

Real Decreto 1578/2008, 26.09.2008, BOE-A-2008-15595

Vyhláška č. 252/2001 Sb. Ministerstva průmyslu a obchodu ze dne 28. června 2001 o způsobu výkupu elektřiny z obnovitelných zdrojů a z kombinované výroby elektřiny a tepla [Decree No. 252/2001], 28.06.2001

Zákon kterým se mění zákon č. 165/2012 Sb., o podporovaných zdrojích energie a o změně některých zákonů, ve znění zákona č. 407/2012 Sb., a další související zákony [Law 310/2013], 02.10.2013, 310/2013 Sb. 
Zákon kterým se mění zákon č. 180/2005 Sb., o podpoře výroby elektřiny z obnovitelných zdrojů energie a o změně některých zákonů (zákon o podpoře využívání obnovitelných zdrojů) [Law 137/2010], 20.05.2010, 137/2010 Sb.

Zákon kterým se mění zákon č. 180/2005 Sb., o podpoře výroby elektřiny z obnovitelných zdrojů energie a o změně některých zákonů (zákon o podpoře využívání obnovitelných zdrojů), ve znění pozdějších předpisů [Law 330/2010], 30.11.2010, 330/2010 Sb.

Zákon kterým se mění zákon č. 180/2005 Sb., o podpoře výroby elektřiny z obnovitelných zdrojů energie a o změně některých zákonů (zákon o podpoře využivání obnovitelných zdrojů), ve znění pozdějších předpisů, a některé další zákony [Law 402/2010], 28.10.2015, 402/2010 Sb.

Zákon o podmínkách podnikání a o výkonu státní správy v energetických odvětvích a o změně některých zákonů (energetický zákon) [Law on business conditions and public administration in energy sectors and amending certain laws; Energy Act 2000], 28.11.2000, 458/2000 Sb.

Zákon o podpoře výroby elektřiny z obnovitelných zdrojů energie a o změně některých zákonů (zákon o podpoře využívání obnovitelných zdrojů) [Law 180/2005], 05.05.2005, 180/2005 Sb.

Zákon o podporovaných zdrojích energie a o změně některých zákonů [Law 165/2012], 30.05.2012, 165/2012 Sb.

\subsection{Books and articles}

Black's Law Dictionary (9 edn, Thomson Reuters 2009)

Alvik I, Contracting with sovereignty: state contracts and international arbitration (Bloomsbury Publishing 2011)

Banet C, Tradable green certificates schemes under EU law (Faculty of Law, University of Oslo 2012)

Behn D and Fauchald OK, 'Governments under Cross-fire? Renewable Energy and International Economic Tribunals' (2015) 12 Manchester Journal of International Economic Law 117-139 
Behn D, Fauchald OK and Letourneau-Tremblay L, 'Promoting Renewable Energy in the EU: Shifting Trends in Member State Policy Space' (2015 forthcoming) European Business Law Review

Blanchard S and Brower CN, "From" Dealing in Virtue" to" Profiting from Injustice": The Case Against" Re-Statification" of Investment Dispute Settlement' (2014) 55 Harvard International Law Journal

Brocka-Balbi Z, 'The Rise and Fall of the Italian Scheme of Support for Renewable Energy From Photovoltaic Plants' (2015) 12 Transnational Dispute Management

Crabbe V, Understanding Statutes (Taylor \& Francis 1994)

Dolzer R, 'Fair and Equitable Treatment: Today's Contours' (2013) 12 Santa Clara J Int'I L 7

Dolzer R and Schreuer C, Principles of international investment law (Oxford University Press 2012)

Feliziani C, 'The Impact of the EU Energy Policy on Member States' Legal Orders: State of Art and Perspectives of Renewable Energy in Italy and Great Britain' (2013) 5 Review of European Studies

Føllesdal A, 'Epilogue: toward More Legitimate Multilevel Regulation' in Andreas Føllesdal, Ramses A. Wessel and Wouters J (eds), Multilevel Regulation and the EU (Martinus Nijhoff Publishers 2008)

Hobér K, 'Investment Arbitration and the Energy Charter Treaty' (2010) 1 Journal of International Dispute Settlement 153-190

Jacobs D, Renewable energy policy convergence in the EU: the evolution of feed-in tariffs in Germany, Spain and France (Ashgate Publishing 2012)

Kavanova L, 'Economy \& Business: Why Czech Solar Investors Feel Burned' (2011) Transitions Online

Kent A, 'Renewable Energy Disputes Before International Economic Tribunals: A Case for Institutional 'Greening'?' (2015) 12 Transnational Dispute Management 
Massari SF, 'The Italian Photovoltaic Sector in two Practical Cases: How to Create an Unfavorable Investment Climate in Renewables' (2015) 12 Transnational Dispute Management

Nathanson RA, 'The revocation of clean-energy investment economic-support systems as indirect expropriation post-nykomb: A spanish case analysis' (2013) 98 lowa Law Review 863-904

Reuter A, 'Retroactive Reduction of Support for Renewable Energy and Investment Treaty Protection from the Perspective of Shareholders and Lenders' (2015) 12 Transnational Dispute Management

Shan W and Zhang S, 'The Treaty of Lisbon: Half Way toward a Common Investment Policy' (2010) 21 European Journal of International Law 1049-1073

Sornarajah M, 'Good Faith, Corporate Nationality, and Denial of Benefits' in Mitchell AD, Sornarajah M and Voon T (eds), Good Faith and International Economic Law (Oxford University Press 2015)

Stone J, 'Arbitrariness, the fair and equitable treatment standard, and the international law of investment' (2012) 25 Leiden Journal of International Law 77 107

Tirado J, 'Renewable Energy Claims under the Energy Charter Treaty: An Overview' (2015) 12 Transnational Dispute Management

Van Harten G, Sovereign Choices and Sovereign Constraints: Judicial Restraint in Investment Treaty Arbitration (Oxford University Press 2013)

Yang C-HWK-C, 'Aggressive Legalism: China's Proactive Role in Renewable Energy Trade Disputes?' (2015) 12 Transnational Dispute Management

\subsection{Online sources}

'Cenové rozhodnutí Energetického regulačního úřadu č. 1/2014 ze dne 12. listopadu 2014, kterým se stanovuje podpora pro podporované zdroje energie [ERO Price Decision No. 1/2014]' (Energetický regulační úřad, 2014) $<$ http://www.eru.cz/cs/poze/cenova-rozhodnuti> accessed 25.10.2015

'Conto Energia: termine ultimo per l'invio delle richieste di riconoscimento degli incentivi' (Gestore dei Servizi Energetici GSE, 2013) 
$<$ http://www.gse.it/it/salastampa/news/Pages/Conto-Energia-termine-ultimo-per-

l\%E2\%80\%99invio-delle-richieste-di-riconoscimento-degli-incentivi.aspx>

accessed 15.10 .2015

'El gobierno español aprueba los nuevos recortes al sector renovable' ( $P V$ Magazine Latinoamérica, 2014) <http://www.pv-magazinelatam.com/noticias/detalles/articulo/el-gobierno-espaol-aprueba-los-nuevosrecortes-al-sector-renovable 100015591/> accessed 24.10.2015

'Fifth feed-in scheme' (Gestore dei Servizi Energetici GSE) $<$ http://www.gse.it/en/feedintariff/Photovoltaic/FifthFeedinScheme/Pages/default.aspx> accessed 15.10.2015

'Gabriel: Brüssel gibt grünes Licht für das EEG' (Bundesministerium für Wirtschaft und Energie, 2014) $<$ http://www.bmwi.de/DE/Presse/pressemitteilungen, did=647364.html> accessed 10.10.2015

'Real Decreto 413/2014, de 6 de junio, por el que se regula la actividad de producción de energía eléctrica a partir de fuentes de energía renovables, cogeneración y residuos' (Hogan Lovells, 2014) <http://goo.gl/3dNGRd> accessed 03.10 .2015

'Slew of Spanish lawsuits filed over renewable energy reforms' (Reuters Africa, 2014)

<http://af.reuters.com/article/energyOilNews/idAFL6NORO4JP20140923> accessed 31.07.2015

'Spalma-incentivi, assoRinnovabili: "ritardo decreti impedisce scelta, si proroghi il termine"' (Qualenergia.It, 2014) $<$ http://www.qualenergia.it/articoli/20141114-spalma-incentivi-assorinnovabili-algoverno-urge-decreto-su-accesso-ai-finanziamenti-bancari> accessed 04.11.2015

'Zweite Anhörungsrunde zur EEG-Novelle: Stellungnahmen zum überarbeiteten Gesetzentwurf' (Bundesministerium für Wirtschaft und Energie, 2014) $<$ http://bmwi.de/DE/Themen/Energie/Erneuerbare-Energien/EEG2014/stellungnahmen-zweite-runde.html > accessed 10.10.2015 
'Öffentlichkeitsbeteiligung zur EEG-Novelle stößt auf großes Interesse' (Bundesministerium für Wirtschaft und Energie, 2014) $<$ http://bmwi.de/DE/Themen/Energie/Erneuerbare-Energien/EEG2014/stellungnahmen-erste-runde.html> accessed 10.10.2015

Baltag C, 'What's New with the Energy Charter Treaty?' (Kluwer Arbitration Blog, 2015) <http://kluwerarbitrationblog.com/blog/2015/06/13/whats-new-with-theenergy-chartertreaty/?utm source=feedburner\&utm medium=email\&utm campaign=Feed\%3A+ KluwerArbitrationBlogFull+\%28Kluwer+Arbitration+Blog+-+Latest+Entries\%29> accessed 31.07.2015

Brauch MD, 'Yukos v. Russia: Issues and legal reasoning behind US $\$ 50$ billion awards' (IISD, 2014) <https://www.iisd.org/itn/2014/09/04/yukos-v-russiaissues-and-legal-reasoning-behind-us50-billion-awards/> accessed 24.11.2015

Cameron P, 'The Energy Charter Treaty Provisions On Low Carbon Investment' (Energy Charter Secretariat, 2012) $<$ http://www.encharter.org/fileadmin/user upload/Publications/LowCarbon Investment 2013.pdf> accessed 02.08.2015

del Río P and Mir-Artigues P, 'A Cautionary Tale: Spain's solar PV investment bubble' (International Institute for Sustainable Development, 2014) $<$ http://www.iisd.org/gsi/sites/default/files/rens ct spain.pdf> accessed 02.10.2015

Desierto DA, 'Beneficial Ownership and International Claims for Economic Damage: Occidental Petroleum v. Ecuador and Restoring Limits to Investor-State Arbitral Tribunals' Jurisdiction Ratione Personae' (EJIL: Talk!, 2015) $<$ http://www.ejiltalk.org/beneficial-ownership-and-international-claims-foreconomic-damage-restoring-limits-to-investor-state-arbitral-tribunals-jurisdiction-inoccidental-petroleum-v-ecuador/> accessed 16.11.2015

Díaz B, 'Las renovables en operación se retribuirán según una "rentabilidad razonable" del 7,5\% en España' ( $P V$ Magazine, 2013) <http://goo.gl/bkvvMV> accessed 03.10.2015 
Elward D, 'Czech Republic takes new approach as ECT claims loom' (Global Arbitration

Review, 2011)

$<$ http://globalarbitrationreview.com/news/article/29583/czech-republic-takes-newapproach-ect-claims-loom/> accessed 12.11.2015

Feldman D and others, 'Photovoltaic (PV) Pricing Trends: Historical, Recent, and Near-Term Projections' (U.S. Department of Energy, 2012) <http://www.nrel.gov/docs/fy13osti/56776.pdf> accessed 22.10.2015

Fiorelli GI, 'Italy withdraws from Energy Charter Treaty' (Global Arbitration News, 2015) <http://globalarbitrationnews.com/italy-withdraws-from-energycharter-treaty-20150507/> accessed 31.07.2015

Fouquet $\mathrm{D}$ and Nysten JV, 'Retroactive and retrospective changes and moratoria to RES support' (KeepOnTrack.EU, 2015) $<$ http://www.keepontrack.eu/contents/publicationsbiannualnationalpolicyupdatesve rsions/policy-briefing6-retroactive-and-retrospective-changes-and-moratoria-to-ressupport.pdf> accessed 08.11.2015

Fulton M, Capalino R and Auer J, 'The German Feed-in Tariff: Recent Policy Changes' (Deutsche Bank Research, 2012) <https://goo.gl//VtCPL> accessed 30.09.2015

Fulton $M$ and others, 'GET FiT Program: Global Energy Transfer Feed-In Tariffs for Developing Countries' (DB Climate Change Advisors, Deutsche Bank Group, 2010) <https://institutional.deutscheawm.com/content/ media/GET FIT 042610 FINAL.pdf> accessed 10.11.2015

Hepburn J, 'In Upholding Intra-EU Energy Charter Award, Swiss Court Considers EU State Aid Issue, as Well as Umbrella Clause Reservation and Tribunal's Damages Methodology' (IAReporter, 2015) $<$ http://www.iareporter.com/articles/in-upholding-intra-eu-energy-charter-awardswiss-court-considers-eu-state-aid-issue-as-well-as-umbrella-clause-reservationand-tribunals-damages-methodology/> accessed 10.11.2015

Kleinheisterkamp J, 'The next 10 year ECT investment arbitration: a vision for the future-from a European law perspective' LSE Law, Society and Economy 
Working Papers <https://www.lse.ac.uk/collections/law/wps/WPS2011-

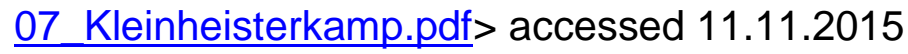

Murray J, 'Spain proposes deep cuts to solar PV support' (The Guardian, 2010) <http://www.theguardian.com/environment/2010/aug/03/spain-cuts-solar-pv> accessed 07.11.2015

Olivet C, 'A test for European solidarity: The case of intra-EU Bilateral Investment Treaties' (Transnational Institute, 2013) $<$ https://www.tni.org/files/download/briefing on intra-eu bits 0.pdf $>$ accessed 12.11.2015

Peterson LE, 'Brussels' Latest Intervention Casts Shadow over Investment Treaty Arbitrations Brought by Jilted Solar Energy Investors' (IAReporter, 2014) $<$ http://www.iareporter.com/articles/brussels-latest-intervention-casts-shadow-overinvestment-treaty-arbitrations-brought-by-jilted-solar-energy-investors/> accessed 10.11 .2015

- -, 'EC Asks Member-States to Signal by Year's End Whether They Will Terminate Their Intra-EU Investment Treaties; Spectre of Legal Action Looms' (IAReporter, 2010) <http://www.iareporter.com/articles/ec-asks-member-states-tosignal-by-years-end-whether-they-will-terminate-their-intra-eu-investment-treatiesspectre-of-legal-action-looms/> accessed 12.11.2015

- , 'Intra-EU Treaty Claims Controversy: New Decisions and Developments in Claims Brought by EU Investors vs. Spain and Hungary' (IAReporter, 2014) $<$ http://www.iareporter.com/articles/intra-eu-treaty-claims-controversy-newdecisions-and-developments-in-claims-brought-by-eu-investors-vs-spain-andhungary/> accessed 08.08.2015

- , 'Investigation: In Recent Briefs, European Commission Casts Doubt on Application of Energy Charter Treaty to Any Intra-EU Dispute' (IAReporter, 2014) $<$ http://www.iareporter.com/articles/investigation-in-recent-briefs-europeancommission-casts-doubt-on-application-of-energy-charter-treaty-to-any-intra-eudispute/> accessed 10.11.2015 
- , 'Solar Investors File Arbitration Against Czech Republic; Intra-EU Bits and Energy Charter Treaty at Center of Dispute' (IAReporter, 2013) $<$ http://www.iareporter.com/articles/solar-investors-file-arbitration-against-czechrepublic-intra-eu-bits-and-energy-charter-treaty-at-center-of-dispute/> accessed 14.11.2015

Peterson LE and Williams Z, 'ICSID Renewables Claims Against Spain Reach 23, Along With Some Signs of Repeat Arbitrator Appointments - But No Common Chairs As Yet' (IAReporter, 2015) $<$ http://www.iareporter.com/articles/icsid-renewables-claims-against-spain-reach23-along-with-some-signs-of-repeat-arbitrator-appointments-but-no-commonchairs-as-yet/> accessed 18.11.2015

Sedlák M, 'Cloudy skies over Czech photovoltaics' (The Energiewende Blog, 2014) <http://energytransition.de/2014/10/cloudy-skies-over-czech-photovoltaics/> accessed 14.11.2015 
ANNEX

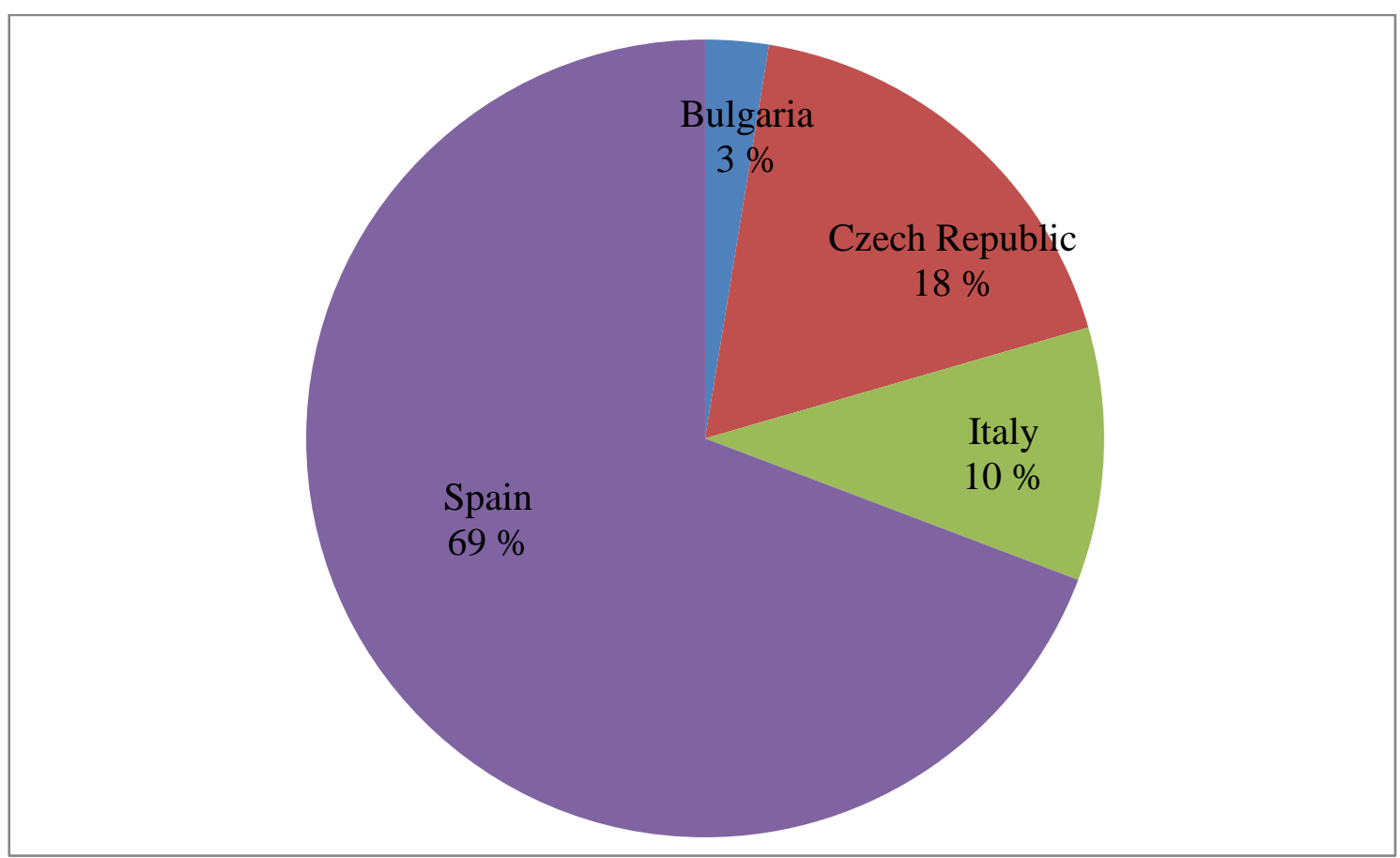

Figure 1 Host states (39 cases)

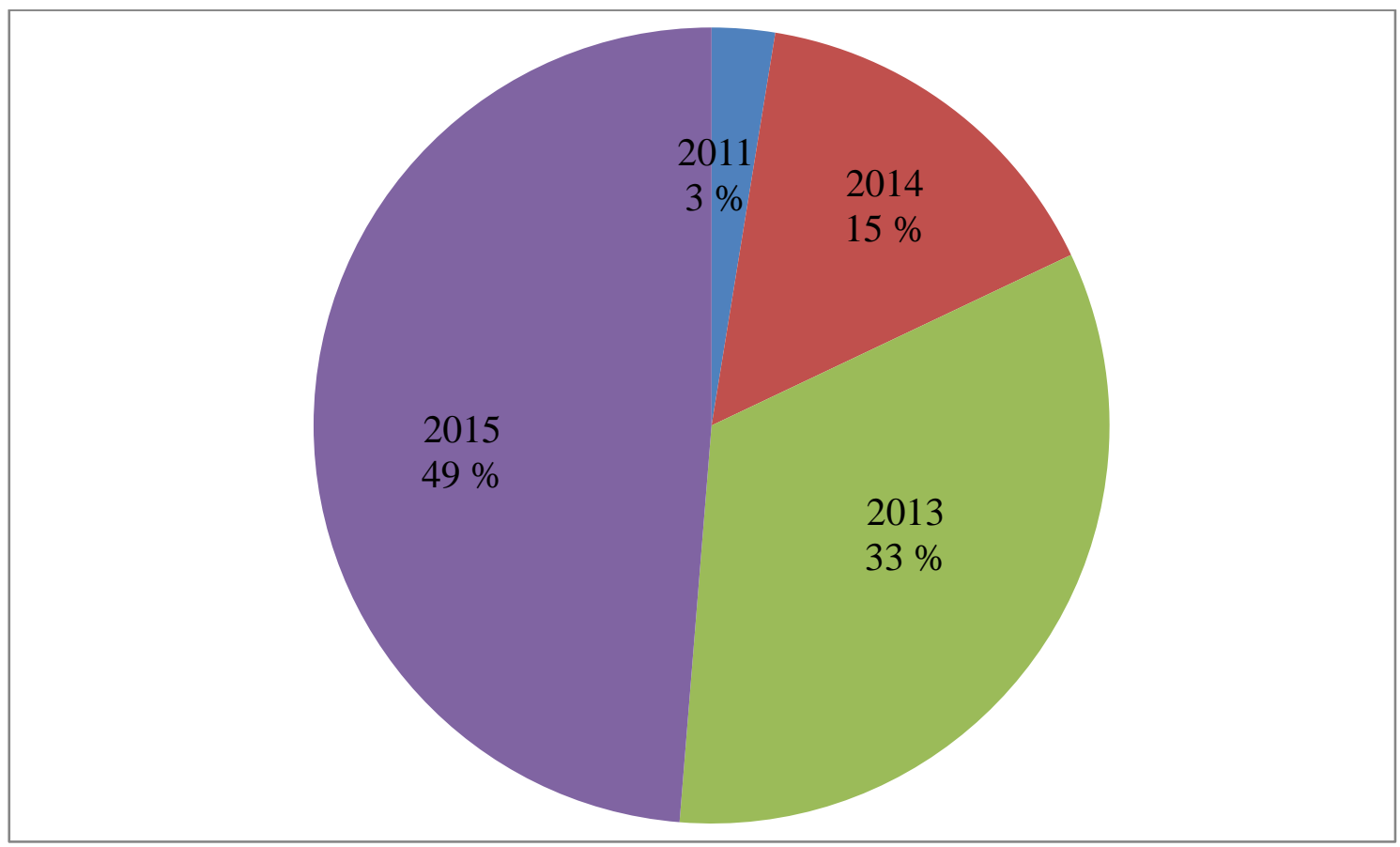

Figure 2 Year of registration (39 cases) 


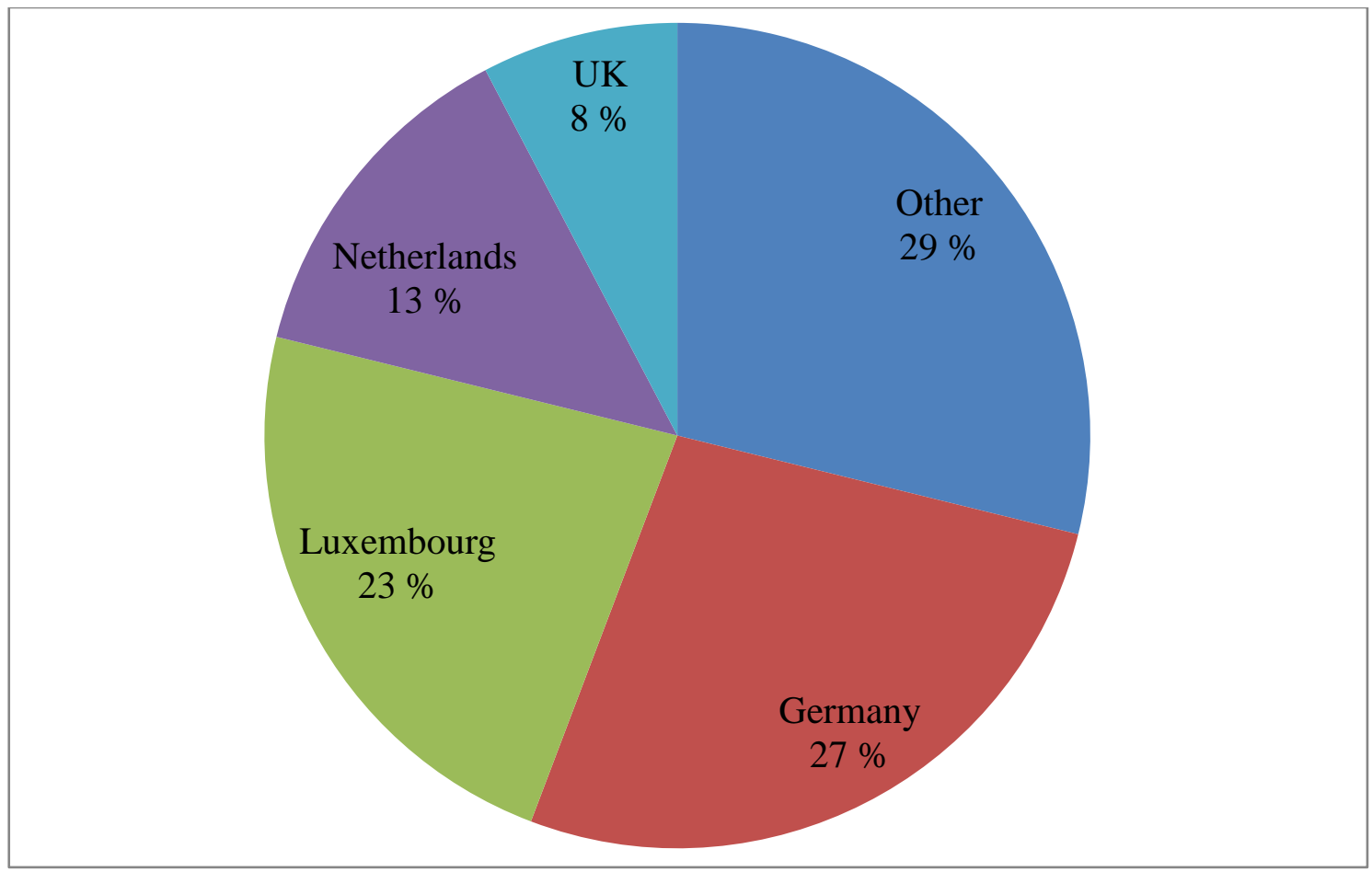

Figure 3 The home state of the investor (39 cases)

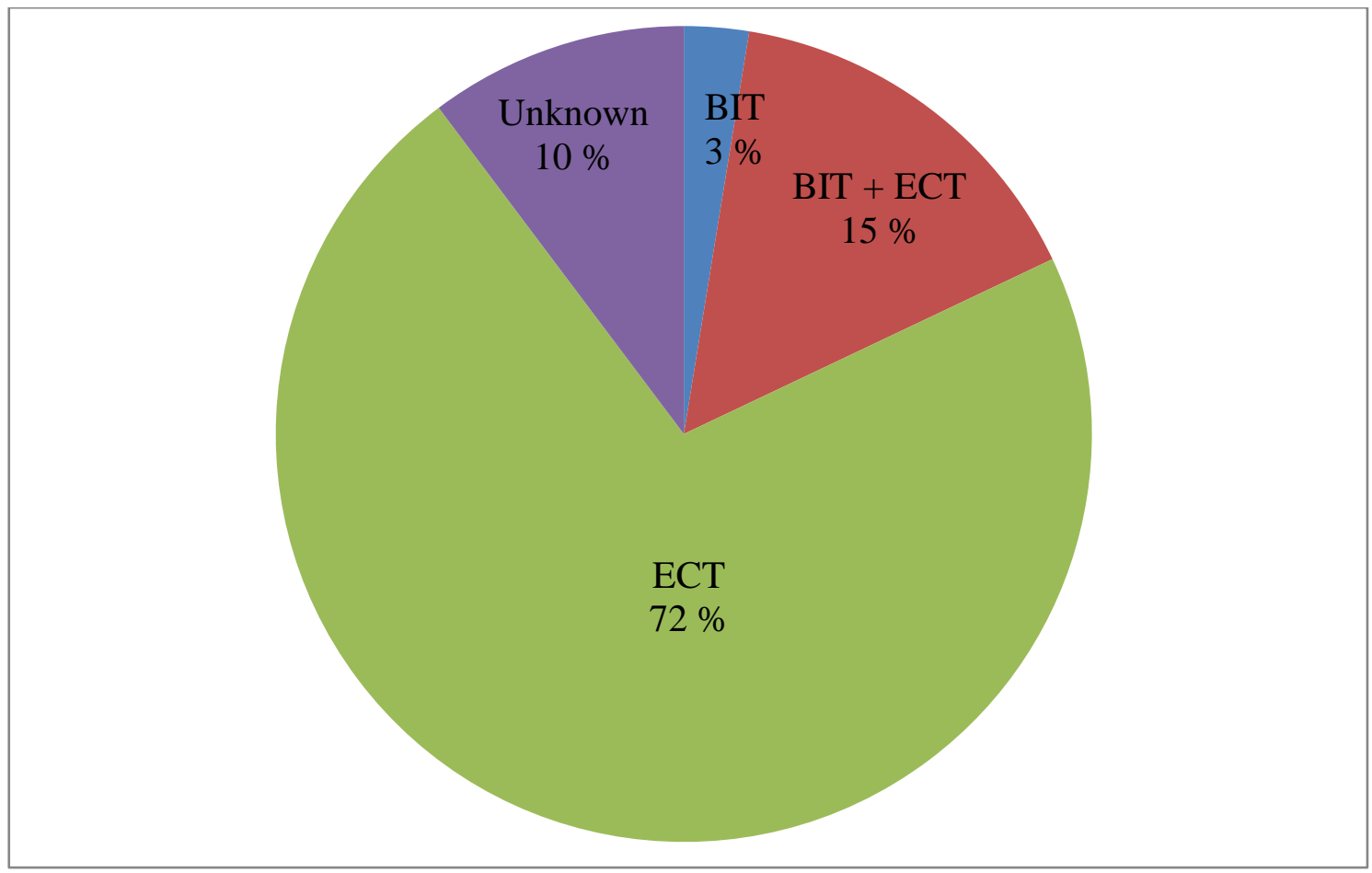

Figure 4 Legal instruments invoked (39 cases) 


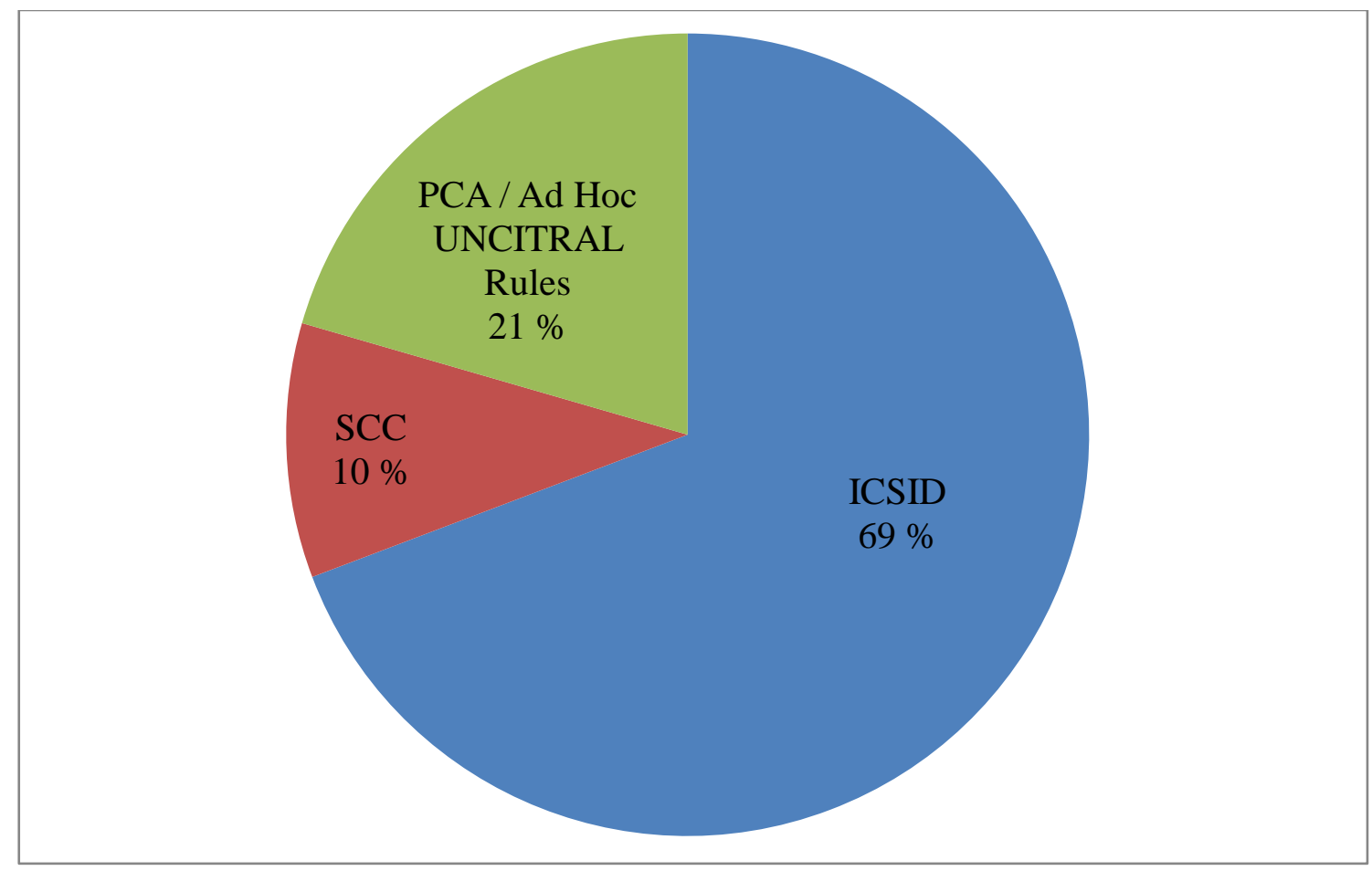

Figure 5 Arbitral forum (39 cases)

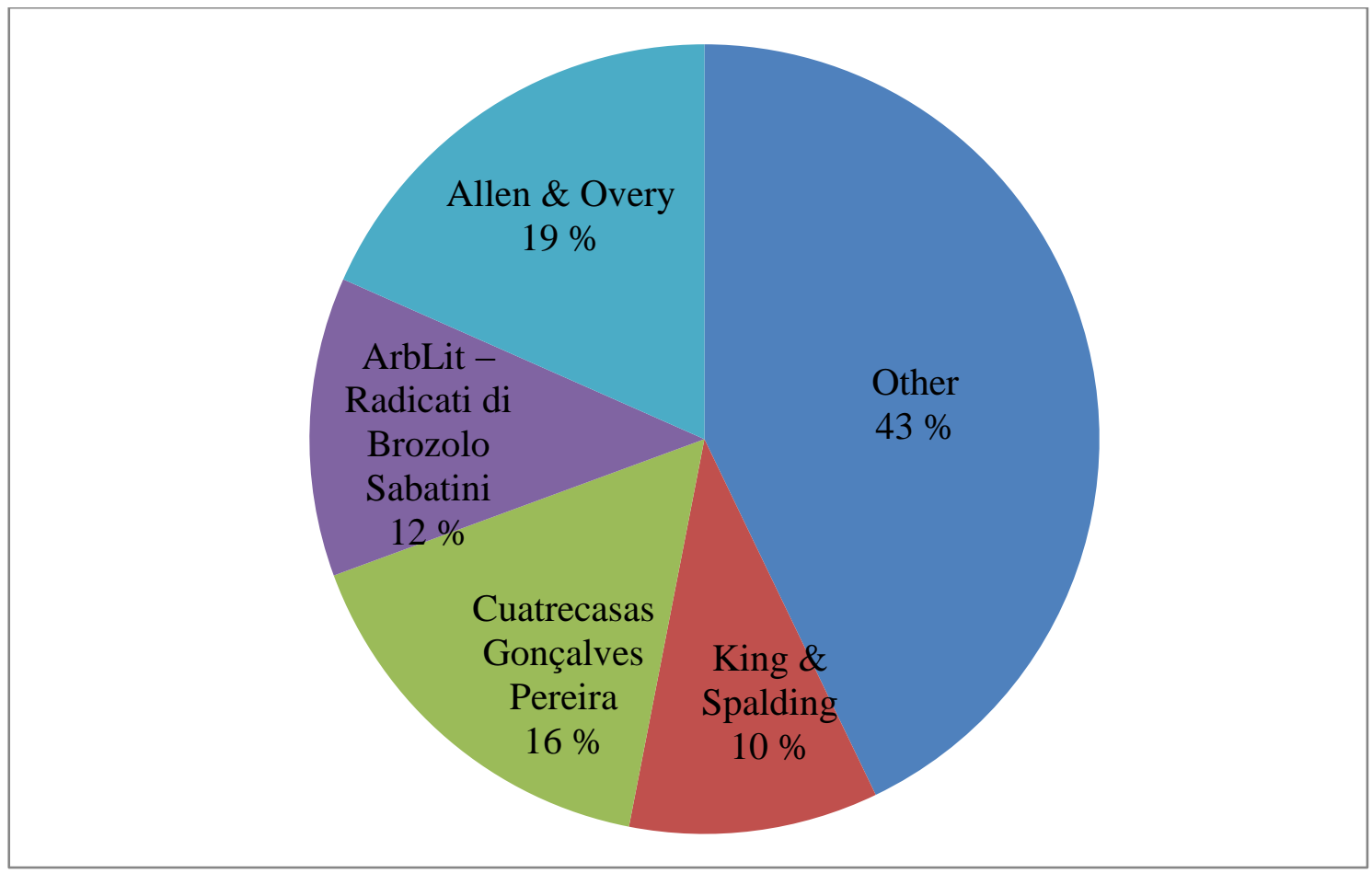

Figure 6 Claimant legal counsel (39 cases) 


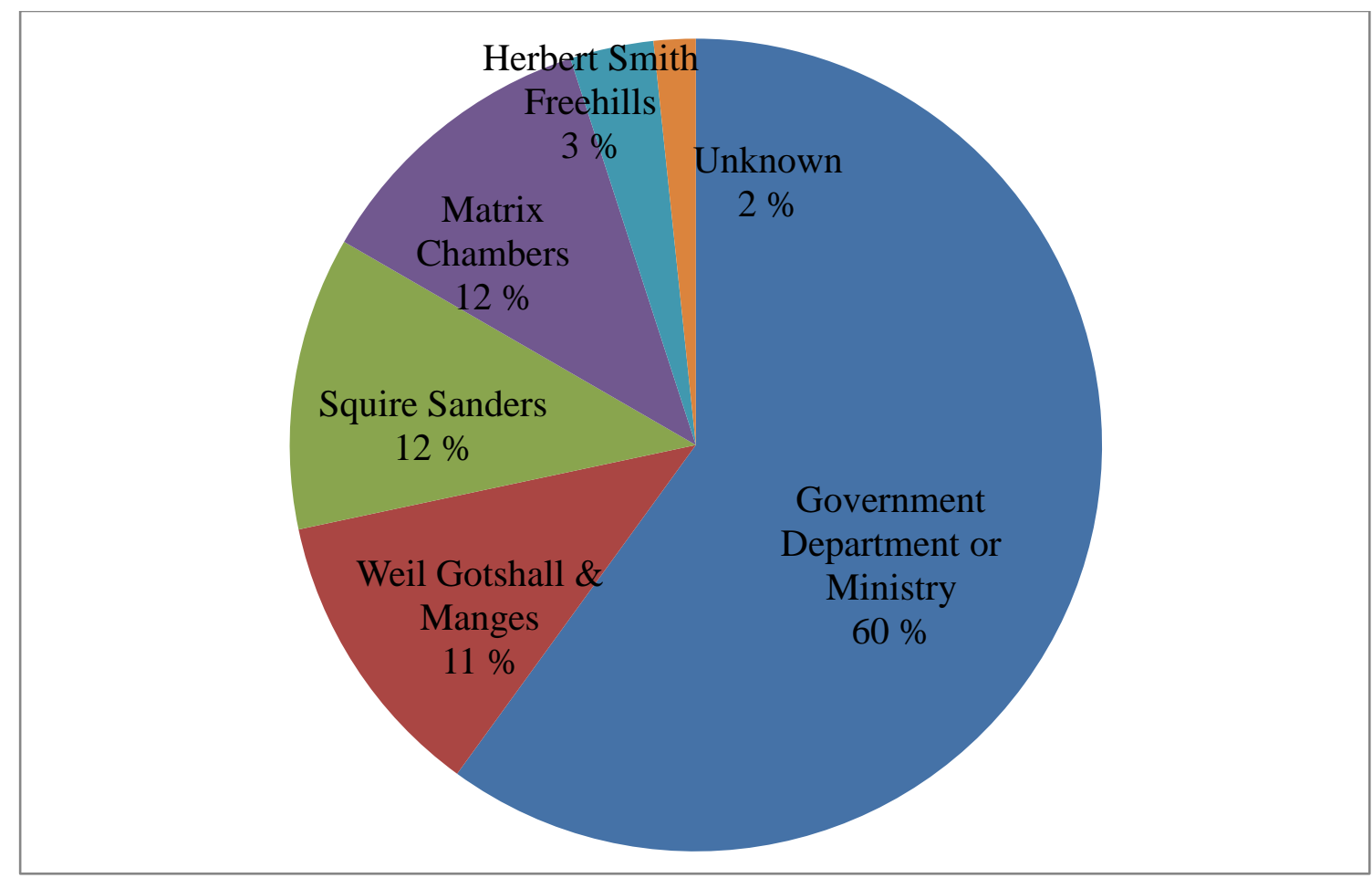

Figure 7 Respondent legal counsel (39 cases) 